\title{
Alien Species Threat across Marine Protected Areas of Turkey-An Updated Inventory
}

\author{
Murat Bilecenoğlu ${ }^{1, *(\mathbb{D})}$ and Melih Ertan Çınar ${ }^{2}$ (D) \\ 1 Department of Biology, Faculty of Arts \& Sciences, Aydın Adnan Menderes University, Aydın 09010, Turkey \\ 2 Department of Hydrobiology, Faculty of Fisheries, Ege University, Bornova, İzmir 35100, Turkey; \\ melih.cinar@ege.edu.tr \\ * Correspondence: mbilecenoglu@adu.edu.tr
}

Citation: Bilecenoğlu, M.; Çınar, M.E. Alien Species Threat across Marine Protected Areas of Turkey-An Updated Inventory. J. Mar. Sci. Eng. 2021, 9, 1077. https://doi.org/ $10.3390 /$ jmse 9101077

Academic Editors: Panayota

Koulouri, Vasilis Gerovasileiou and Thanos Dailianis

Received: 27 August 2021

Accepted: 25 September 2021

Published: 1 October 2021

Publisher's Note: MDPI stays neutral with regard to jurisdictional claims in published maps and institutional affiliations.

Copyright: (c) 2021 by the authors. Licensee MDPI, Basel, Switzerland. This article is an open access article distributed under the terms and conditions of the Creative Commons Attribution (CC BY) license (https:// creativecommons.org/licenses/by/ $4.0 /)$.
Abstract: This study presents the first comprehensive assessment of alien species occurrences within the selected 11 Marine Protected Areas (MPAs) located on the Aegean and Levantine coasts of Turkey. The inventory includes a total of 289 species belonging to 15 phyla, in which lowest and highest diversities were observed in Saros Bay MPA (27 species, northern Aegean Sea) and Fethiye-Göcek Bay MPA (150 species, northwest Levantine Sea), respectively. Alien species distributions that were revealed in protected areas located in the southern Aegean and Levantine Seas were $56.9 \%$ similar (based on presence vs. absence data), while northern Aegean sites formed another distinct group. According to the breakdown of major phyla through the entire study areas, Mollusca had the highest alien diversity (22.1\% of alien species), followed by Actinopterygii (19.0\%), Arthropoda (15.2\%) and Annelida (13.5\%). Casual aliens were represented by very low proportions in each MPA, proving that most species were already established in the region, with a significant proportion of invasive species. Regardless of the localities, the majority of the species originated from the Red Sea, whose primary pathway of introduction is the corridor, the Suez Canal. In the absence of effective management actions against bioinvasions, MPAs located along the Turkish coastline do not currently seem to provide any protection, revealing a large conservation gap to be filled.

Keywords: invasive alien species; marine protected areas; eastern Mediterranean Sea

\section{Introduction}

In the Mediterranean Sea, Marine Protected Areas (MPAs) are described as clearly defined marine geographical spaces (including subtidal, intertidal and supratidal ecosystems, together with coastal lakes/lagoons connected permanently or temporarily to the sea), which are recognized, dedicated and managed through legal or other effective means, to achieve the long-term conservation of nature with its associated ecosystem services and cultural values [1]. As clearly implied by this broad generic term, MPAs are the most effective conservation tool in the key management of marine ecosystem alterations around the world [2], by maintaining natural ecological processes, increasing ecosystem resilience, preserving genetic diversity, ensuring the sustainable utilization of species and ecosystems, restoring the biomass and structure of species assemblages, and providing socio-economic benefits [3-5]. These advantages, however, can only be noticeable in appropriately sited, strongly protected and effectively managed MPAs [3], which prominently protect natural habitats and species from multiple local human stressors, e.g., overexploitation of living resources and habitat destruction [6]. The recent assessments of the development of MPAs in the Mediterranean Sea during the last decade show progress towards the increased protection of marine and coastal areas; however, results are not encouraging and effectiveness of management measures are still a matter of concern [7]. Currently, 9.7\% of the Mediterranean Sea is designated as MPAs, but only a small portion are associated with a properly implemented management plan and few countries have fulfilled the designated 
target of $10 \%$ by 2020 , pointed out both in the UN Sustainable Development Goal 14 and Aichi target 11 (Convention on Biological Diversity) [8].

MPAs appear to be quite vulnerable when the enormous impacts of global-scale stressors such as climate change, pollution and biological invasions are taken into consideration [9]. The latter phenomenon is of special importance throughout the Mediterranean Sea, since the basin is among the most ecologically altered marine regions globally, representing a hotspot of biological invasions [10,11]. Human-mediated alien species introductions are regarded as one of the main causes of drastic biodiversity changes in the region, causing a troublesome problem because of the unprecedented rate of their invasion, and the irreversible impacts they pose on local ecosystems, human health and the socio-economy $[12,13]$, and so their impact on protected areas could thus be much more severe $[14,15]$. Despite the widespread theory that MPAs are resistant to invasion owing to their high species diversity and putative abundance of predators, competitors and parasites of alien species, this hypothesis is not fully supported and marine reserves may even promote the introduction of alien species $[10,16]$. Through the wealth of research carried out so far, very few attempts have been made to clarify the status of alien species within coastal protected areas, in which the available information denotes that majority of Mediterranean MPAs are at a high risk of invasion [17] and their boundaries offer almost no protection from many high-impact invasive species [18].

Biodiversity and ecosystem conservation in Turkey is ensured by protected areas dispersed in 15 different categories (National Parks, Special Environment Protection Areas, Strict Nature Reserves, etc.), managed officially by two governmental bodies (Ministry of Agriculture and Forestry and Ministry of Environment and Urbanization). Currently, about $6.8 \%$ of Turkey's marine areas are nominally protected, which is significantly lower than the reported regional and global figures [8,19]. As with most parts of the Mediterranean Sea, alien and invasive species inventories specifically concentrated on MPAs are scarce in Turkey, where existing information is provided by a series of government-funded projects in the early 2000s [20-22], clearly outdated and seeking critical revisions. In order to promote the development of coordinated efforts and management measures throughout the Mediterranean Sea, a basin-specific action plan concerning species introductions and invasive species was recently published [23]. Considering the knowledge gaps to be filled on various issues, contracting countries are recommended to give national priority to take all necessary actions (scientific research and monitoring, national impact assessments, etc.) for improving the available knowledge, and conducting baseline and monitoring studies to obtain reliable data on the distribution of marine alien species. Conforming to the existing international commitments, Turkey has recently set its first national objective through the National Biodiversity Action Plan 2018-2028 [24] to determine the pressures and threats to biodiversity and ecosystems, including mitigating the impacts of alien species.

The success of the regulation of the prevention and management of invasive species relies heavily on the compilation of alien species inventories [25], which provide early warning of potentially invasive species, both within a country and for neighboring countries, and constitute an important tool for the implementation of relevant policies [26,27]. It is imperative that such inventories remain current and updated regularly by accurate scientific information, since the alien status of several species is constantly changing based on genetic studies, taxonomic revisions and biogeographic reviews [28]. Owing to the large knowledge gap regarding alien species occurrences through the MPAs in Turkey, we carried out a critical revision of their distribution, origin and modes of introduction, which are policy-relevant attributes of the utmost importance. No marine area in the world is immune to invasions and no action can be taken without such core biodiversity data. This is the first comprehensive treatment of alien taxa inhabiting MPAs in Turkey, which provides a scientific basis for further management actions and the effective allocation of resources. 


\section{Materials and Methods}

Selection of the study sites was made according to their marine terrain coverage. Among the existing coastal and marine protected areas in Turkey, only those with over $40 \mathrm{~km}^{2}$ of marine space were considered, including 7 MPAs in the Aegean Sea and 4 in the Levantine Sea (Table 1, Figure 1). Despite its huge area of nearly $11,000 \mathrm{~km}^{2}$, the Finike Seamounts special environment protection area (northwest Levant) was omitted from the analyses, since the area was characterized by unique habitats (i.e., mud volcanoes) hosting deep sea species and currently no data on the existence of any alien species were available.

Table 1. General information on studied MPAs of Turkey (NP: national park, SEPA: special environmental protection area).

\begin{tabular}{|c|c|c|c|c|c|}
\hline MPA Name & $\begin{array}{l}\text { Protection } \\
\text { Status }\end{array}$ & Year Founded & $\begin{array}{c}\text { Surface Area } \\
\left(\mathrm{km}^{2}\right)\end{array}$ & $\begin{array}{l}\text { Marine Coverage } \\
\left(\mathrm{km}^{2}\right)\end{array}$ & $\begin{array}{c}\text { Coastal Length } \\
(\mathbf{k m})\end{array}$ \\
\hline \multicolumn{6}{|l|}{ Aegean Sea } \\
\hline 1. Saros Bay & SEPA & 2010 & 730 & 538 & 62 \\
\hline 2. Ayvalik Islands & NP & 1995 & 180 & 142 & 110 \\
\hline 3. Foça & SEPA & 1990 & 71 & 52 & 28 \\
\hline 4. Karaburun-Ildır Bay & SEPA & 2019 & 947 & 502 & 127 \\
\hline 5. Gökova Bay & SEPA & 1988 & 1093 & 820 & 193 \\
\hline $\begin{array}{l}\text { 6. Datça-Bozburun } \\
\text { Peninsula }\end{array}$ & SEPA & 1990 & 1444 & 737 & 417 \\
\hline 7. Köyceğiz-Dalyan & SEPA & 1988 & 461 & 41 & 26 \\
\hline \multicolumn{6}{|l|}{ Levantine Sea } \\
\hline 8. Fethiye-Göcek Bay & SEPA & 1988 & 805 & 339 & 196 \\
\hline 9. Patara & SEPA & 1990 & 197 & 45 & 23 \\
\hline 10. Kaş-Kekova & SEPA & 1990 & 258 & 158 & 81 \\
\hline 11. Göksu Delta & SEPA & 1990 & 229 & 98 & 35 \\
\hline
\end{tabular}

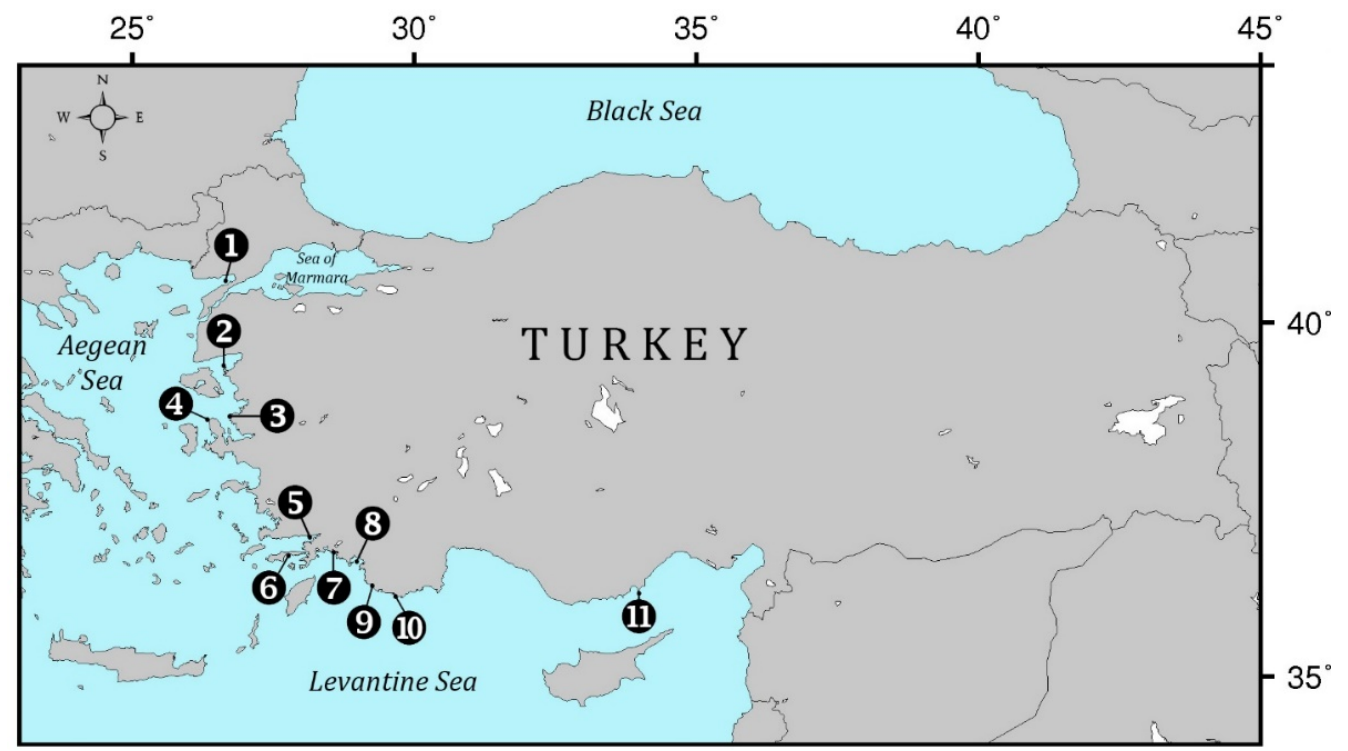

Figure 1. Geographical location of the studied MPAs (description of numerals as in Table 1).

In order to determine marine faunal hotspots in Turkey, species occurrence records (comprising all extant taxa) associated with accurate locality information and/or exact coordinates were plotted on a map where the Turkish coasts were divided into equivalent squares of $15 \times 15 \mathrm{~km}^{2}$, which were then entered into an Excel file for further analysis (for full account see [29]). Initial entries were based on governmental marine biodiversity studies conducted at 8 MPAs [20-22,30-33], with a number of alien taxa as follows: Saros Bay (5 sp.), Ayvalık Islands (5 sp.), Foça (1 sp.), Gökova Bay (26 sp.), Datça-Bozburun Peninsula (33 sp.), Köyceğiz-Dalyan (10 sp.), Fethiye-Göcek Bay (93 sp.), Kaş-Kekova (71 sp.); no baseline inventory was available for Karaburun-Ildır, Patara and Göksu Delta. 
An updated version of this file (including floral elements) focusing solely on alien taxa was used in a recent comprehensive inventory [12], which formed the core data of the present study. For better presenting the distributional patterns of alien species, we also included previously unpublished observations (not new for the country or the region but overlooked occurrences in corresponding MPAs). The presence vs. absence matrix was used to reveal similarities within the MPAs, using cluster analysis with a group average sorting performed with the PRIMER 5.2 software [34].

The terminology of alien species followed [10], referring to species introduced by human activities, while species undergoing climate-shifted range expansions, without humanassisted spread, were not considered to be alien. Species that formed self-maintaining populations with at least two records in the area (three records for fish) spread over time and space, were classified as established species, while those having been recorded only once (no more than twice for fish) with no evidence of self-sustaining populations were classified as casual species [12]. Established aliens whose populations had proliferated and rapidly expanded their distributional range by overcoming biotic and abiotic barriers in the region were treated as invasive species [35]. Only primary pathways were considered in the classification of the pathways for the alien species introductions to Turkey (corridor via the Suez Canal, ships and aquaculture). Cryptogenic (species with no definite evidence of their native or introduced status) and questionable species were all left out of the inventory. Origins of each species were examined under 12 categories (IP: Indo-Pacific, RS: Red Sea, AT: Atlantic, NA: North Atlantic, WA: Western Atlantic, ST: Subtropical Atlantic/Pacific, IO: Indian Ocean, PG: Persian Gulf, PO: Pacific Ocean, TA: Tropical Atlantic, CT: Circumtropical, Unk: Unknown).

\section{Results}

The alien species inventory of Turkish MPAs included a total of 289 species belonging to 15 phyla, the majority of which had established successfully breeding populations throughout the study sites $(61.6 \%)$ and a significant portion displayed an invasive character (29.4\%) (Appendix A). Mollusca ranked first in terms of the number of alien species (64 sp.), followed by Chordata (55 sp.), Arthropoda (44 sp.) and Annelida (39 sp.). Percentage distribution of alien species phyla in each MPA is presented in Table 2.

Table 2. Percentage distribution of alien species phyla in Turkish MPAs.

\begin{tabular}{|c|c|c|c|c|c|c|c|c|c|c|c|}
\hline Phyla & Saros & Ayvalık & Foça & Karaburun & Gökova & Datça & Köyceğiz & Fethiye & Patara & Kaş & Göksu \\
\hline Ochrophyta & 11.1 & 20.0 & 3.1 & 8.2 & 2.3 & 2.8 & & 2.0 & 3.2 & 2.1 & 2.2 \\
\hline Chlorophyta & 7.4 & 8.6 & 6.3 & 4.1 & 2.3 & 1.9 & 1.4 & 2.0 & 4.3 & 2.1 & 1.4 \\
\hline Rhodophyta & 14.8 & 11.4 & 6.3 & 12.3 & 5.8 & 4.7 & & 5.3 & 8.6 & 5.6 & 5.1 \\
\hline Tracheophyta & & 2.9 & 3.1 & 1.4 & 1.2 & 0.9 & 1.4 & 0.7 & 1.1 & 0.7 & \\
\hline Foraminifera & 18.5 & 17.1 & & 19.2 & 1.2 & 12.3 & & 1.3 & 14.0 & 15.3 & \\
\hline Cnidaria & & & & & 2.3 & 4.7 & 4.3 & 2.0 & & 0.7 & 0.7 \\
\hline Ctenophora & 3.7 & & & & 1.2 & & & 0.7 & & 0.7 & \\
\hline Sipuncula & & & 3.1 & 1.4 & 1.2 & 0.9 & & 0.7 & & & \\
\hline Annelida & 7.4 & 20.0 & 34.4 & 19.2 & 14.0 & 12.3 & 14.5 & 18.0 & 8.6 & 13.2 & 12.3 \\
\hline Arthropoda & 18.5 & 5.7 & 3.1 & 12.3 & 17.4 & 10.4 & 10.1 & 16.7 & 10.8 & 13.9 & 12.3 \\
\hline Mollusca & 7.4 & & 3.1 & 6.8 & 9.3 & 12.3 & 13.0 & 16.7 & 8.6 & 16.0 & 30.4 \\
\hline Bryozoa & & & & 2.7 & & & & 1.3 & & & \\
\hline Echinodermata & & & & & 2.3 & 1.9 & 2.9 & 2.0 & 1.1 & 1.4 & 0.7 \\
\hline Tunicata & & & 6.3 & & & 2.8 & 1.4 & 5.3 & 2.2 & 1.4 & 0.7 \\
\hline Chordata & 11.1 & 14.3 & 31.3 & 12.3 & 39.5 & 32.1 & 50.7 & 25.3 & 37.6 & 27.1 & 34.1 \\
\hline
\end{tabular}

There were significant differences in local alien biodiversity, with a clear decreasing pattern in a clockwise direction from Levantine towards the northern Aegean Sea coasts. The cluster analysis showed that MPAs were clearly separated into two groups (northern Aegean Sea areas vs. southern Aegean Sea and Levant Sea combined) at 30.0\% similarity, which split further at $46.0 \%$ and $56.9 \%$ similarities (Figure 2). The numbers of taxa were typically higher in Levantine localities (ranging from 93 to $150 \mathrm{sp}$.), gradually decreasing to 
69-106 sp. in the southern Aegean Sea and the minimum values were observed northwards, at values between 27 to $73 \mathrm{sp}$.

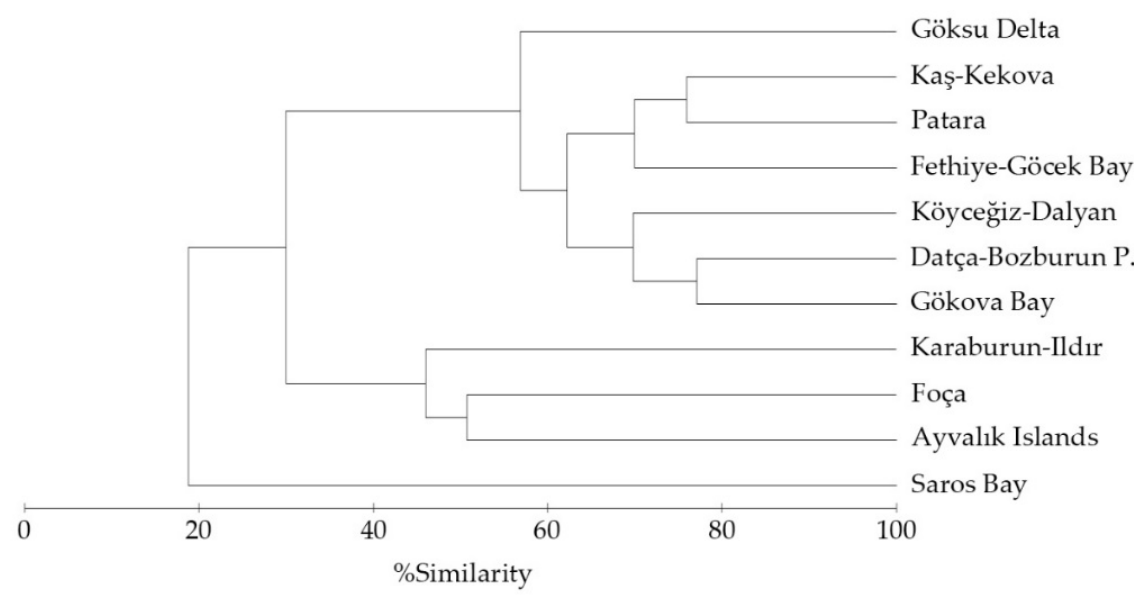

Figure 2. Group average sorting dendrogram of Turkish MPAs based on binary data (presence and absence) of alien taxa.

It is striking that the number of casual aliens is quite low throughout the entire study area (none in Foça and Köyceğiz-Dalyan, ranging from 1.2\% to $6.9 \%$ elsewhere), where the great majority of the species are either characterized by successfully breeding established populations or possess an invasive character (Figure 3). The proportion of invasive taxa ranged from $37.0 \%$ (Göksu Delta) to $62.3 \%$ (Köyceğiz-Dalyan), displaying a largescale impact regardless of their occurrence localities. The two invasive fish, Lagocephalus sceleratus (Gmelin, 1789) and Siganus rivulatus (Forsskål, 1775) were present in each of the MPAs, while some other noxious species, such as Caulerpa cylindracea (Sonder, 1845) (Chlorophyta), Asparagopsis armata (Harvey, 1855) (Rhodophyta), Leodice antennata (Savigny, 1820) (Annelida), etc., were absent in just a few sites.

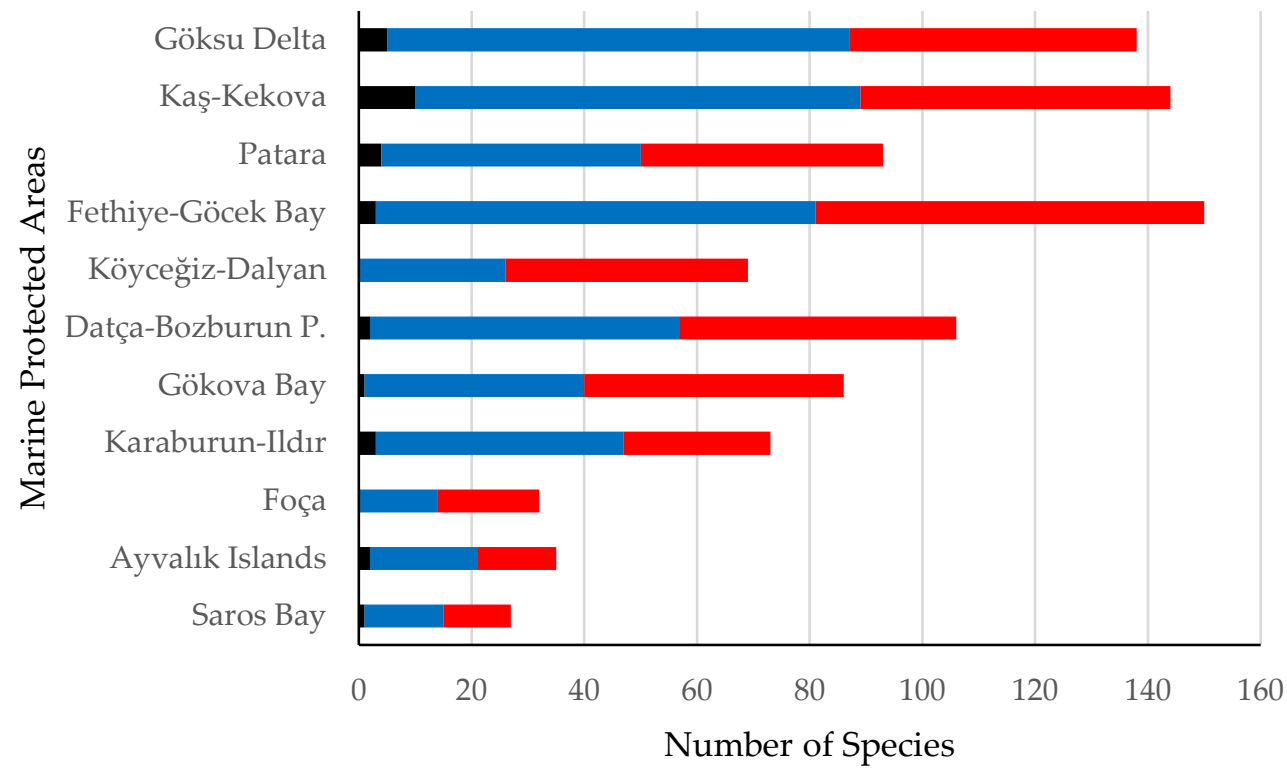

- Casual — Established — Invasive

Figure 3. Establishment success of alien taxa in MPAs. 
According to their origins, there was a very pronounced dominance of Red Sea originated species (201 sp., out of 289 sp.), while the contribution of rest of the categories was set at low levels (Figure 4). This was an expected result, since Turkey was geographically located close to the Red Sea, which explained why corridors (Suez Canal) were the main vector of the species introductions (Figure 5). Ship-transferred species were higher in proportion at the north Aegean MPAs (Saros Bay, Ayvalık Islands, Foça and Karaburun-Ildır, ranging between $28.1-48.1 \%$ ), significantly reducing to levels of $8.7-18.0 \%$ in the rest of the coastal areas. Saros Bay was the only locality that shipping-oriented introductions outnumbered Suez Canal introductions (13 sp. vs. 9 sp., respectively); the latter vector was dominant elsewhere. Aquaculture was the least impacting vector and only four such species were present in MPAs (for example, the Pacific Ocean originated invasive bivalve Ruditapes philippinarum (Adams \& Reeve, 1850)).

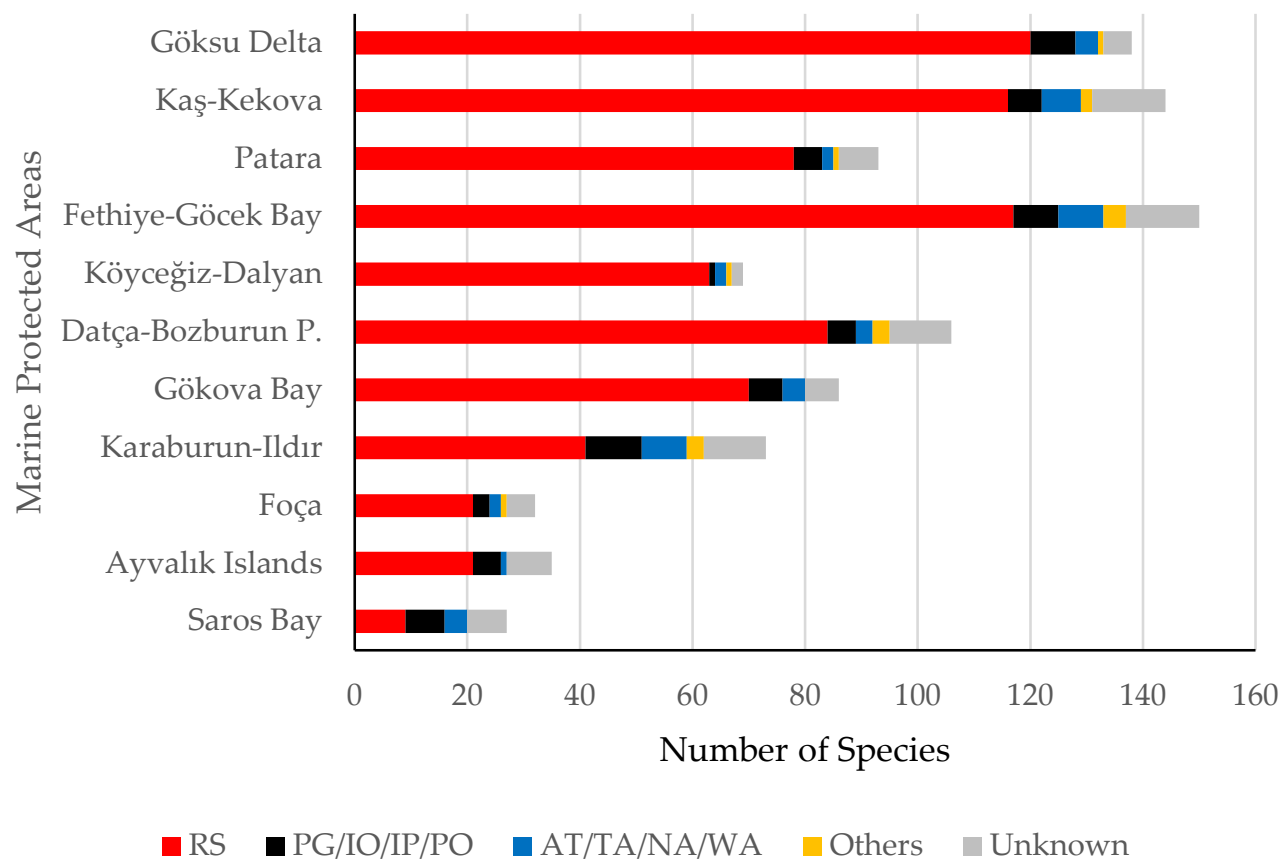

Figure 4. Origins of alien taxa in MPAs. For ease of interpretation, low contributing origins were grouped: red group, RS: Red Sea; black group, PG: Persian Gulf, IO: Indian Ocean, IP: Indo-Pacific, PO: Pacific Ocean; blue group, AT: Atlantic, TA: Tropical Atlantic, NA: North Atlantic, WA: Western Atlantic; yellow group (others), ST: Subtropical Atlantic/Pacific, CT: Circumtropical; grey group, species with currently unknown origin). 


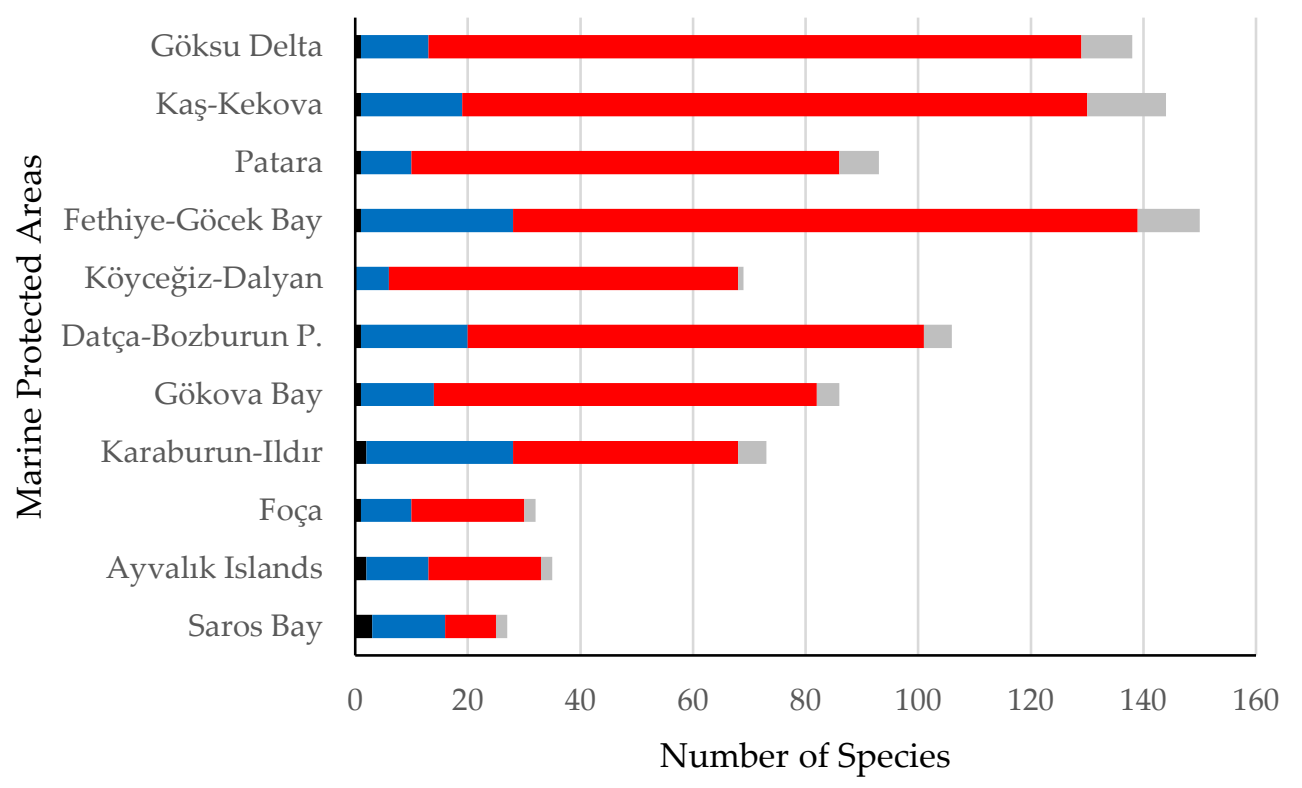

- Aquaculture $\quad$ Ships $\quad$ Corridor Unknown

Figure 5. Pathways of the introduction of alien taxa in MPAs.

\section{Discussion}

The present inventory revealed that (i) existing MPAs were exposed to different levels of alien biota impact, with a clear decreasing trend from the Levantine coasts to the northernmost regions of the Aegean Sea; (ii) the Suez Canal was the most important vector for species introductions, and was also responsible for the existence of the huge proportion of Red Sea-originated biota; and (iii) the high rates of established aliens and invasive species were obvious in every MPA. These results were in accordance with the general trends observed for the alien biota of the entire coast of Turkey during the last decade [12,35]. The low number of species determined in the northern Aegean protected areas should be carefully monitored, since they may be related to lower research efforts, in comparison to the northern Levantine coasts. The significant taxonomic similarity we found between the southern Aegean and Levantine MPAs was an issue to be taken seriously and may have indicated an ongoing biotic homogenization event, although concrete data for proving this phenomenon are currently lacking. It is a known fact that species invasions and extinctions lead to a decrease in $\beta$-diversity, by increasing the genetic, taxonomic or functional similarity of two or more locations over time [36].

When Mediterranean Sea coastal countries were taken into consideration, more alien taxa were recorded along the Turkish coastline than anywhere else. For example, the reported diversity was $452 \mathrm{sp}$. in Israel [37], $265 \mathrm{sp}$. in Italy [38], $214 \mathrm{sp}$. in Greece [39], $136 \mathrm{sp}$. in Tunisia [40] and $73 \mathrm{sp}$. in Libya [41]. Receiving 185 new alien species introductions just during the last decade, the immense impact of bioinvasions to the Turkish marine realm reflected the diversity estimates, now reaching to 539 species, 404 of which were established in the region [12]. Thus, it was not surprising that there was a high number of alien species (289 sp.) throughout Turkish MPAs, which we believe was merely an underestimation and could certainly be increased by further research. The relevant data are currently incomparable to any other regional datasets, due to the lack of country-based comprehensive alien species checklists, which focus on their presence in protected areas of the Mediterranean Sea. As previously outlined, Mediterranean MPAs face common challenges including a lack of baseline information and the inefficient reporting of biological invasions $[10,18,42]$, constituting crucial data to draw robust conclusions in the effective management of protected sites [14,43]. 
No control of alien species is feasible that would not also harm other components of the biota once an invasion process is underway $[10,44]$, thus the objective highlighted in the Convention on Biological Diversity (CBD) at art. 8(h), calling for contracting parties "as far as possible and as appropriate, (to) prevent the introduction of, control or eradicate those alien species which threaten ecosystems, habitats or species" can only be partially fulfilled, especially by the eastern Mediterranean countries where the existing invasion process is unique. By ratifying and signing the "International Convention for the Control and Management of Ship's Ballast Water and Sediments" in 2014, Turkey took an important step that could considerably decrease risks of ship-borne introductions, but the troublesome vector, the Suez Canal, remains wide open, unquestioningly destroying the strength of the proposed eradication measures. The first ever government-supported incentive notification on the bounty hunting of the noxious Lagocephalus sceleratus along Turkish coasts (for a price of EUR 0.5 per each captured individual) ended with little success, where only 46,000 individuals were eradicated out of the targeted 1 million fish [12]. Although L. sceleratus fishery was also conducted within the existing MPAs, the captured quantities in each site have not been announced yet. The above-mentioned notification has been updated recently (official gazette no. 31524, dated 27 June 2021), now encouraging the capture of all Tetraodontids inhabiting Turkey (native pufferfish were incomprehensibly included as well) from now until the end of 2023. There are also efforts to cull and create consumption demand to decrease the population trend of Pterois miles in the Kaş-Kekova region [45], though currently no official announcement has been made.

MPAs alone are unlikely to be sufficient in preventing biological invasions in the Mediterranean Sea, as evidenced from results of several recent studies [46-49]. On the contrary, the Red Sea invaders, which came from a highly competitive environment, find a suitable feeding and shelter ground in the Mediterranean MPAs, whereby they increase their population sizes enormously and utilize the areas as stepping stones in their distribution expansions [16]. Therefore, alien species' harvesting should be promoted in MPAs where they benefit from fishing bans and restrictions that apply within the MPAs. Considering the highly connected nature of the Mediterranean Sea, a basin-wide ecosystembased policy on bioinvasions is required [10]. The effective management of the Suez Canal is of utmost importance, and an issue which all Mediterranean countries have failed to put on their conservation agendas so far, highlighting the urgent need of international cooperation in the management of alien species [12].

In terms of their resilience to invasive species, an unmanaged MPA is no different from an unprotected coastal area, reflecting the current situation we are experiencing in Turkey. The drastic impact of invaders are therefore the expected and inevitable result of numerous "lacks", including a lack of legal background, lack of marine management plans (available only for Foça, Gökova Bay and Kaş-Kekova with no measures defined against the struggle with aliens), the lack of public/governmental awareness and understanding of the impacts of invasive species, the lack of trained staff devoted to monitor the impacts of alien taxa, the lack of funds to regularly carry out monitoring research (at least for selected invasive species), and the lack of fishery regulations in favor of apex predators, etc.

Author Contributions: Conceptualization, M.B., M.E.Ç.; methodology, M.B., M.E.Ç.; analysis, M.B., M.E.Ç.; writing—original draft preparation, M.B., M.E.Ç.; writing—reviewing and editing, M.B., M.E.Ç. All authors have read and agreed to the published version of the manuscript.

Funding: This research received no external funding.

Institutional Review Board Statement: Not applicable.

Informed Consent Statement: Not applicable.

Data Availability Statement: Data is contained within the article.

Conflicts of Interest: The authors declare no conflict of interest.

\section{Appendix A}




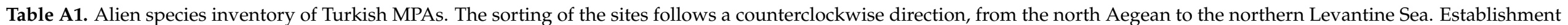

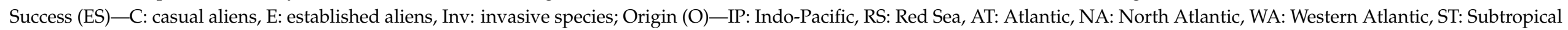

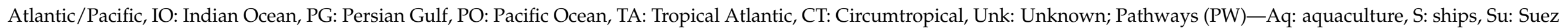
Canal (corridor).

\begin{tabular}{|c|c|c|c|c|c|c|c|c|c|c|c|c|c|c|}
\hline Species List & Saros Bay & Ayvalık & Foça & Karaburun & Gökova Bay & Datça & Köyceğiz & Fethiye & Patara & Kaş-Kekova & Göksu & ES & $\mathbf{O}$ & PW \\
\hline \multicolumn{15}{|l|}{ Ochrophyta } \\
\hline Botrytella parva (Takamatsu) H.-S.Kim, 1996 & & 1 & & & & & & & & & & $\mathrm{C}$ & IP & $\mathrm{S}$ \\
\hline Cladosiphon zosterae (J.Agardh) Kylin, 1940 & & 1 & & 1 & & & & & & & 1 & $\mathrm{E}$ & AT & $\mathrm{S}$ \\
\hline Cutleria multifida (Turner) Greville, 1830 & 1 & 1 & & 1 & 1 & 1 & & 1 & 1 & 1 & 1 & $\mathrm{E}$ & IP & $\mathrm{Aq}$ \\
\hline $\begin{array}{l}\text { Dictyota cyanoloma Tronholm, De Clerck, } \\
\text { Gomez Garreta \& Rull Lluch, } 2010\end{array}$ & & & & 1 & & & & & & & & $\mathrm{E}$ & ST & $\mathrm{S}$ \\
\hline Halothrix lumbricalis (Kützing) Reinke, 1888 & 1 & 1 & & 1 & & & & 1 & 1 & 1 & & $\mathrm{E}$ & Unk & $\mathrm{S}$ \\
\hline Sphaerotrichia firma (Gepp) A.D.Zinova, 1940 & & 1 & & & & 1 & & & & & & $\mathrm{E}$ & Unk & $\mathrm{S}$ \\
\hline $\begin{array}{l}\text { Stypopodium schimperi (Buchinger ex } \\
\text { Kützing) Verlaque \& Boudouresque, } 1991\end{array}$ & & 1 & 1 & 1 & 1 & 1 & & 1 & 1 & 1 & 1 & Inv & RS & ?Su \\
\hline \multicolumn{15}{|l|}{ Chlorophyta } \\
\hline Caulerpa cylindracea Sonder, 1845 & 1 & 1 & 1 & 1 & 1 & 1 & 1 & 1 & 1 & 1 & & Inv & RS & $\mathrm{Su}$ \\
\hline $\begin{array}{l}\text { Caulerpa racemosa var. lamourouxii f. requienii } \\
\text { (Montagne) Weber-van Bosse, } 1898\end{array}$ & & & & & & & & 1 & 1 & 1 & 1 & E & RS & $\mathrm{Su}$ \\
\hline $\begin{array}{l}\text { Caulerpa taxifolia var. distichophylla (Sonder) } \\
\text { Verlaque, Huisman\&Procacin, } 2013\end{array}$ & & & & & & & & & & & 1 & Inv & $\mathrm{PO}$ & $\mathrm{S}$ \\
\hline $\begin{array}{l}\text { Codium fragile subsp. fragile (Suringar) } \\
\text { Hariot, } 1889\end{array}$ & 1 & 1 & 1 & 1 & 1 & 1 & & & & & & Inv & Unk & $\mathrm{S}$ \\
\hline $\begin{array}{l}\text { Codium parvulum (Bory ex Audouin) } \\
\text { P.C.Silva, } 2003\end{array}$ & & 1 & & & & & & & & & & $\mathrm{E}$ & RS & $\mathrm{Su}$ \\
\hline Codium taylorii P.C. Silva, 1960 & & & & 1 & & & & & & & & $\mathrm{E}$ & IP & $\mathrm{S}$ \\
\hline $\begin{array}{l}\text { Pseudocodium okinawense E.J.Faye, } \\
\text { M.Uchimura \& S.Smimada, } 2008\end{array}$ & & & & & & & & & 1 & & & C & $\mathrm{PO}$ & $\mathrm{S}$ \\
\hline
\end{tabular}


Table A1. Cont.

\begin{tabular}{|c|c|c|c|c|c|c|c|c|c|c|c|c|c|c|}
\hline Species List & Saros Bay & Ayvalık & Foça & Karaburun & Gökova Bay & Datça & Köyceğiz & Fethiye & Patara & Kaş-Kekova & Göksu & ES & $\mathbf{O}$ & PW \\
\hline \multicolumn{15}{|l|}{ Rhodophyta } \\
\hline $\begin{array}{l}\text { Acanthophora nayadiformis (Delile) Papenfuss, } \\
1968\end{array}$ & 1 & & & 1 & & & & 1 & 1 & 1 & 1 & E & RS & $\mathrm{Su}$ \\
\hline Asparagopsis armata Harvey, 1855 & 1 & 1 & 1 & 1 & 1 & 1 & & 1 & 1 & 1 & 1 & Inv & Unk & $S$ \\
\hline $\begin{array}{l}\text { Asparagopsis taxiformis (Delile) Trevisan de } \\
\text { Saint-Léon, } 1845\end{array}$ & & & & 1 & & & & & & & & Inv & RS & $\mathrm{Su}$ \\
\hline Bonnemaisonia hamifera Hariot, 1891 & & & & 1 & & & & 1 & 1 & 1 & 1 & Inv & IP & ?S \\
\hline $\begin{array}{l}\text { Colaconema codicola (Børgesen) H. Stegenga, } \\
\text { J.J. Bolton, \& R.J. Anderson, } 1997\end{array}$ & 1 & & & & 1 & 1 & & 1 & 1 & 1 & 1 & E & Unk & S \\
\hline $\begin{array}{l}\text { Ganonema farinosum (Lamouroux) Fan \& } \\
\text { Wang, } 1974\end{array}$ & & 1 & & 1 & 1 & 1 & & 1 & 1 & 1 & 1 & E & RS & $\mathrm{Su}$ \\
\hline Hypnea spinella (C. Agardh) Kützing, 1847 & & & & 1 & & & & 1 & 1 & 1 & 1 & $\mathrm{E}$ & $\mathrm{CT}$ & $\mathrm{S}$ \\
\hline $\begin{array}{l}\text { Lophocladia lallemandii (Montagne) Schmitz, } \\
1893\end{array}$ & & 1 & 1 & 1 & 1 & 1 & & 1 & 1 & 1 & 1 & E & RS & $\mathrm{Su}$ \\
\hline Polysiphonia paniculata Montagne, 1842 & & & & 1 & & & & & & & & E & Unk & $\mathrm{S}$ \\
\hline Vertebrata fucoides (Hudson) Kuntze 1891 & & & & 1 & 1 & 1 & & & & & & E & Unk & $\mathrm{S}$ \\
\hline \multicolumn{15}{|l|}{ Tracheophyta } \\
\hline $\begin{array}{l}\text { Halophila stipulacea (Forsskål) Ascherson, } \\
1867\end{array}$ & & 1 & 1 & 1 & 1 & 1 & 1 & 1 & 1 & 1 & & Inv & RS & $\mathrm{Su}$ \\
\hline \multicolumn{15}{|l|}{ Foraminifera } \\
\hline Adelosina longirostra (d'Orbigny, 1826) & & & & & & 1 & & & & & & $\mathrm{C}$ & Unk & $\mathrm{S}$ \\
\hline Amphisorus hemprichii Ehrenberg, 1840 & & & & & & & & 1 & 1 & 1 & & Inv & Unk & $?$ \\
\hline Amphistegina lobifera Larsen, 1976 & & 1 & & 1 & & 1 & & 1 & 1 & 1 & & Inv & RS & $\mathrm{Su}$ \\
\hline Articulina alticostata Cushman, 1944 & & & & & & 1 & & & & & & E & $\mathrm{PO}$ & S \\
\hline Astacolus insolitus (Schwager, 1866) & & & & & 1 & & & & & & & E & $\mathrm{PO}$ & $\mathrm{S}$ \\
\hline Bolivina striatula Cushman, 1922 & 1 & & & & & & & & & & & E & Unk & $?$ \\
\hline Clavulina cf. multicamerata Chapman, 1907 & & & & & & 1 & & & & 1 & & E & RS & $\mathrm{Su}$ \\
\hline
\end{tabular}


Table A1. Cont.

\begin{tabular}{|c|c|c|c|c|c|c|c|c|c|c|c|c|c|}
\hline Species List & Saros Bay & Ayvalık & Foça & Karaburun Gökova Bay & Datça & Köyceğiz & Fethiye & Patara & Kaş-Kekova & Göksu & ES & $\mathrm{O}$ & PW \\
\hline Cornuspiroides striolata (Brady) & & & & 1 & & & & & & & $\mathrm{E}$ & Unk & $\mathrm{S}$ \\
\hline Cyclorbiculina compressa (d'Orbigny, 1839) & & & & & & & & & 1 & & $\mathrm{C}$ & Unk & $?$ \\
\hline Cymbaloporetta plana (Cushman, 1915) & & & & 1 & 1 & & & & 1 & & $\mathrm{E}$ & RS & $\mathrm{Su}$ \\
\hline Cymbaloporetta squammosa (d'Orbigny, 1839) & & & & 1 & 1 & & & & 1 & & $\mathrm{E}$ & Unk & $?$ \\
\hline Entosigmomorphina sp. & & & & & & & & & 1 & & $\mathrm{C}$ & $\mathrm{PO}$ & $\mathrm{S}$ \\
\hline Euthymonacha polita (Chapman, 1904) & & & & 1 & & & & & & & $\mathrm{E}$ & Unk & $\mathrm{S}$ \\
\hline Hauerina diversa Cushman, 1946 & & & & & & & & 1 & 1 & & $\mathrm{E}$ & RS & $\mathrm{Su}$ \\
\hline Heterostegina depressa d'Orbigny, 1826 & & & & & & & & 1 & 1 & & $\mathrm{E}$ & RS & $\mathrm{Su}$ \\
\hline $\begin{array}{l}\text { Iridia diaphana Heron-Allen and Earland, } \\
1914\end{array}$ & & 1 & & 1 & & & & & & & $\mathrm{E}$ & $\mathrm{PO}$ & $\mathrm{S}$ \\
\hline Miliolinella cf. hybrida (Terquem, 1878) & & & & & & & & & 1 & & $\mathrm{C}$ & RS & $\mathrm{Su}$ \\
\hline $\begin{array}{l}\text { Nodophthalmidium antillarum (Cushman, } \\
\text { 1922) }\end{array}$ & & & & 1 & & & & & & & $\mathrm{E}$ & RS & $\mathrm{Su}$ \\
\hline Peneroplis arietinus (Batsch, 1791) & & & & 1 & & & & 1 & 1 & & $\mathrm{E}$ & RS & $\mathrm{Su}$ \\
\hline Peneroplis planatus (Fichtel \& Moll, 1798) & & 1 & & 1 & 1 & & & 1 & 1 & & $\mathrm{C}$ & RS & $\mathrm{Su}$ \\
\hline Planogypsina acervalis (Brady, 1884) & 1 & & & & & & & & & & $\mathrm{E}$ & RS & $\mathrm{Su}$ \\
\hline Planogypsina squamiformis (Chapman, 1901) & 1 & & & & 1 & & & & 1 & & $\mathrm{E}$ & RS & $\mathrm{Su}$ \\
\hline $\begin{array}{l}\text { Pseudomassilina reticulata (Heron-Allen and } \\
\text { Earland, 1915) }\end{array}$ & & & & & & & & 1 & & & $\mathrm{C}$ & RS & $\mathrm{Su}$ \\
\hline Pseudonodosaria brevis (d'Orbigny, 1846) & & & & 1 & & & & & & & $\mathrm{C}$ & $\mathrm{PO}$ & $\mathrm{S}$ \\
\hline $\begin{array}{l}\text { Pulleniatina obliquiloculata (Parker \& Jones, } \\
\text { 1862) }\end{array}$ & 1 & & & & & & & & & & $\mathrm{C}$ & $\mathrm{PO}$ & $\mathrm{S}$ \\
\hline Pyrgo denticulata (Brady, 1917) & & & & & & & & & 1 & & $\mathrm{E}$ & Unk & $?$ \\
\hline Quinqueloculina cf. mosharrafai Said, 1949 & & & & & & & & & 1 & & $\mathrm{C}$ & RS & $\mathrm{Su}$ \\
\hline Schlumbergerina alveoliniformis (Brady, 1879) & 1 & & & & & & & 1 & 1 & & $\mathrm{E}$ & RS & $\mathrm{Su}$ \\
\hline Sorites orbiculus Ehrenberg, 1839 & & 1 & & 1 & 1 & & & 1 & 1 & & $\mathrm{E}$ & Unk & $?$ \\
\hline Sorites variabilis Lacroix, 1941 & & & & 1 & & & & 1 & 1 & & $\mathrm{E}$ & RS & $\mathrm{Su}$ \\
\hline
\end{tabular}


Table A1. Cont.

\begin{tabular}{|c|c|c|c|c|c|c|c|c|c|c|c|c|c|c|}
\hline Species List & Saros Bay & Ayvalık & Foça & Karaburun & Gökova Bay & Datça & Köyceğiz & Fethiye & Patara & Kaş-Kekova & Göksu & ES & $\mathbf{O}$ & PW \\
\hline Spiroloculina angulata Cushman, 1917 & & & & & & 1 & & & 1 & 1 & & $\mathrm{E}$ & RS & $\mathrm{Su}$ \\
\hline Triloculina cf. fichteliana d'Orbigny, 1839 & & & & 1 & & 1 & & & & 1 & & $\mathrm{E}$ & RS & $\mathrm{Su}$ \\
\hline Vaginulinopsis sublegumen Parr, 1950 & & 1 & & & & 1 & & & & & & $\mathrm{E}$ & $\mathrm{PO}$ & $\mathrm{S}$ \\
\hline \multicolumn{15}{|l|}{ Hydrozoa } \\
\hline Clytia linearis (Thorneley, 1900) & & & & & & 1 & & & & & & $\mathrm{E}$ & RS & $\mathrm{Su}$ \\
\hline Filellum serratum (Clarke, 1879) & & & & & & 1 & & & & & & $\mathrm{E}$ & $\mathrm{CT}$ & $\mathrm{S}$ \\
\hline Macrorhynchia philippina Kirchenpauer, 1872 & & & & & & & & 1 & & & & Inv & RS & $\mathrm{Su}$ \\
\hline Sertularia marginata (Kirchenpauer, 1864) & & & & & & 1 & & & & & & $\mathrm{E}$ & $\mathrm{CT}$ & $\mathrm{S}$ \\
\hline \multicolumn{15}{|l|}{ Scyphozoa } \\
\hline Cassiopea andromeda (Forsskål, 1775) & & & & & 1 & 1 & 1 & 1 & & & & Inv & RS & $\mathrm{Su}$ \\
\hline Phyllorhiza punctata von Lendenfeld, 1884 & & & & & & & 1 & & & & & $\mathrm{E}$ & RS & $\mathrm{Su}$ \\
\hline $\begin{array}{l}\text { Rhopilema nomadica Galil, Spanier \& } \\
\text { Ferguson, } 1990\end{array}$ & & & & & 1 & 1 & 1 & 1 & & 1 & 1 & Inv & RS & $\mathrm{Su}$ \\
\hline \multicolumn{15}{|l|}{ Ctenophora } \\
\hline \multicolumn{15}{|l|}{ Sipuncula } \\
\hline $\begin{array}{l}\text { Aspidosiphon (A.) elegans (Chamisso \& } \\
\text { Eysenhardt, 1821) }\end{array}$ & & & 1 & 1 & 1 & 1 & & 1 & & & & $\mathrm{E}$ & RS & $\mathrm{Su}$ \\
\hline \multicolumn{15}{|l|}{ Annelida } \\
\hline Aricidea bulbosa Hartley, 1984 & & 1 & & & & 1 & & & & & & $\mathrm{E}$ & RS & $\mathrm{Su}$ \\
\hline Branchiomma bairdi (McIntosh, 1885) & & & & & & & & 1 & & 1 & & Inv & Unk & ?S \\
\hline Branchiomma luctuosum Grube, 1869 & & & & & & & & 1 & & & & Inv & RS & $\mathrm{Su}$ \\
\hline Ceratonereis mirabilis Kinberg, 1866 & & 1 & 1 & 1 & 1 & 1 & 1 & 1 & & 1 & 1 & $\mathrm{E}$ & RS & $\mathrm{Su}$ \\
\hline Chaetozone corona Berkeley \& Berkeley, 1941 & 1 & 1 & 1 & 1 & 1 & 1 & 1 & 1 & & 1 & & $\mathrm{E}$ & ?PO & $\mathrm{S}$ \\
\hline Dorvillea similis (Crossland, 1924) & & & & 1 & 1 & 1 & 1 & 1 & 1 & 1 & 1 & Inv & RS & $\mathrm{Su}$ \\
\hline Eurythoe complanata (Pallas, 1766) & & & & & 1 & 1 & 1 & 1 & 1 & 1 & 1 & Inv & ?RS & ?Su \\
\hline Eusyllis kupfferi Langerhans, 1879 & & & & & & & & 1 & & 1 & 1 & $\mathrm{E}$ & ?AT & S \\
\hline Exogone africana (Hartmann-Schröder, 1974) & & & & & & & & & & & 1 & $\mathrm{E}$ & RS & $\mathrm{Su}$ \\
\hline
\end{tabular}


Table A1. Cont.

\begin{tabular}{|c|c|c|c|c|c|c|c|c|c|c|c|c|c|c|}
\hline Species List & Saros Bay & Ayvalık & Foça & Karaburun & Gökova Bay & Datça & Köyceğiz & Fethiye & Patara & Kaş-Kekova & Göksu & ES & $\mathrm{O}$ & PW \\
\hline $\begin{array}{l}\text { Exogone breviantennata Hartmann-Schröder, } \\
1959\end{array}$ & & & & & & & & 1 & & 1 & & $\mathrm{E}$ & RS & $\mathrm{Su}$ \\
\hline Ficopomatus enigmaticus (Fauvel, 1923) & & & & & & & 1 & & & & & Inv & ST & $\mathrm{S}$ \\
\hline Glycinde bonhourei Gravier, 1904 & & & & & & & & & & & 1 & $\mathrm{E}$ & RS & $\mathrm{Su}$ \\
\hline Hydroides dirampha Mörch, 1863 & & & & & & & & 1 & & & & Inv & $\mathrm{CT}$ & $\mathrm{S}$ \\
\hline Hydroides elegans (Haswell, 1883) & & & 1 & 1 & & 1 & & 1 & & 1 & & Inv & $\mathrm{CT}$ & $\mathrm{S}$ \\
\hline Laonice norgensis Sikorski, 2003 & & & & & 1 & & & & & & & $\mathrm{C}$ & AT & $\mathrm{S}$ \\
\hline Leodice antennata (Savigny, 1820) & & 1 & 1 & 1 & 1 & 1 & 1 & 1 & 1 & 1 & 1 & Inv & RS & $\mathrm{Su}$ \\
\hline Leonnates indicus Kinberg, 1866 & & & & & & & & 1 & & 1 & & Inv & RS & $\mathrm{Su}$ \\
\hline Leonnates persicus Wesenberg-Lund, 1949 & & 1 & 1 & 1 & 1 & 1 & & 1 & & 1 & 1 & $\mathrm{E}$ & RS & $\mathrm{Su}$ \\
\hline Linopherus canariensis Langerhans, 1881 & & & & & & & & 1 & & 1 & 1 & $\mathrm{E}$ & AT & $\mathrm{S}$ \\
\hline Loimia medusa (Savigny, 1818) & & & & & & & & 1 & & & & E & RS & ?Su \\
\hline Lumbrineris perkinsi Carrera-Parra, 2001 & & & & & & & & 1 & 1 & 1 & 1 & $\mathrm{E}$ & RS & ?Su \\
\hline Lysidice collaris Grube, 1870 & & 1 & 1 & 1 & & & & 1 & & & & $\mathrm{E}$ & RS & $\mathrm{Su}$ \\
\hline Notomastus aberans Day, 1957 & & & 1 & 1 & 1 & 1 & 1 & 1 & 1 & 1 & 1 & $\mathrm{E}$ & RS & $\mathrm{Su}$ \\
\hline Notomastus mossambicus (Thomassin, 1970) & & & & & & & & & & & 1 & Inv & RS & $\mathrm{Su}$ \\
\hline Palola valida (Gravier, 1900) & & & & 1 & & & & 1 & 1 & 1 & 1 & $\mathrm{E}$ & RS & $\mathrm{Su}$ \\
\hline Phyllodoce longifrons Ben-Eliahu, 1972 & & & & & & & & 1 & & & & $\mathrm{E}$ & RS & $\mathrm{Su}$ \\
\hline Pista unibranchia Day, 1963 & & 1 & 1 & 1 & 1 & 1 & & 1 & & 1 & & $\mathrm{E}$ & RS & $\mathrm{Su}$ \\
\hline Polycirrus twisti Potts, 1928 & & & & & & & & 1 & & 1 & 1 & E & RS & $\mathrm{Su}$ \\
\hline Polydora cornuta Bosc, 1802 & & & & 1 & & & & & & & & Inv & WA & $\mathrm{S}$ \\
\hline Prionospio (Minuspio) pulchra Imajima 1990 & & & 1 & & & & & 1 & & & & Inv & IP & $\mathrm{S}$ \\
\hline $\begin{array}{l}\text { Prionospio (Prionospio) depauperata Imajima, } \\
1990\end{array}$ & 1 & & & & & & & & & & 1 & Inv & $\mathrm{PO}$ & $\mathrm{S}$ \\
\hline $\begin{array}{l}\text { Prionospio (Prionospio) paucipinnulata Blake \& } \\
\text { Kudenov, } 1978\end{array}$ & & & & & 1 & & & & & & & $\mathrm{E}$ & $\mathrm{PO}$ & $\mathrm{S}$ \\
\hline $\begin{array}{l}\text { Prionospio (Prionospio) saccifera Mackie \& } \\
\text { Hartley, } 1990\end{array}$ & & & & & & 1 & 1 & 1 & & & & $\mathrm{E}$ & RS & $\mathrm{Su}$ \\
\hline Pseudonereis anomala Gravier, 1900 & & & & 1 & 1 & 1 & 1 & 1 & 1 & 1 & 1 & Inv & RS & $\mathrm{Su}$ \\
\hline
\end{tabular}


Table A1. Cont.

\begin{tabular}{|c|c|c|c|c|c|c|c|c|c|c|c|c|c|c|}
\hline Species List & Saros Bay & Ayvalık & Foça & Karaburun & Gökova Bay & Datça & Köyceğiz & Fethiye & Patara & Kaş-Kekova & Göksu & ES & $\mathbf{O}$ & PW \\
\hline Pseudopolydora paucibranchiata Okuda, 1937 & & & & 1 & & & & & & & & Inv & IP & $\mathrm{S}$ \\
\hline Spirorbis marioni Caullery \& Mesnil, 1897 & & & 1 & & & & & & & & & E & $\mathrm{PO}$ & $\mathrm{S}$ \\
\hline Streblospio gynobranchiata Rice \& Levin, 1998 & & & 1 & 1 & & & & & & & & Inv & WA & $\mathrm{S}$ \\
\hline Syllis ergeni Çinar, 2005 & & & & & 1 & 1 & 1 & 1 & 1 & 1 & 1 & Inv & RS & $\mathrm{Su}$ \\
\hline \multicolumn{15}{|l|}{ Cladocera } \\
\hline Pleopis schmackeri (Poppe, 1889) & 1 & & & 1 & 1 & & & & & & & $\mathrm{E}$ & IP & $\mathrm{Su} / \mathrm{S}$ \\
\hline \multicolumn{15}{|l|}{ Copepoda } \\
\hline Oithona davisae Ferrari and Orsi, 1984 & & & & 1 & & & & & & & & Inv & $\mathrm{PO}$ & $\mathrm{S}$ \\
\hline Paracartia grani Sars G.O., 1904 & & & & 1 & & & & & & & & $\mathrm{E}$ & AT & $\mathrm{S}$ \\
\hline \multicolumn{15}{|l|}{ Stomatopoda } \\
\hline Clorida albolitura Ahyong \& Naiyanetr, 2000 & & & & & & & & & & & 1 & $\mathrm{E}$ & RS & $\mathrm{Su}$ \\
\hline Erugosquilla massavensis (Kossmann, 1880) & & 1 & & & 1 & & & 1 & 1 & 1 & 1 & Inv & RS & $\mathrm{Su}$ \\
\hline \multicolumn{15}{|l|}{ Amphipoda } \\
\hline $\begin{array}{l}\text { Ampithoe bizseli Özaydınlı and Coleman, } \\
2012\end{array}$ & & & & 1 & & & & & & & & E & $\mathrm{IP}$ & $\mathrm{S}$ \\
\hline $\begin{array}{l}\text { Latigammaropsis togoensis (Schellenberg, } \\
\text { 1925) }\end{array}$ & & & & & & & & & & & 1 & E & Unk & ?S \\
\hline \multicolumn{15}{|l|}{ Isopoda } \\
\hline Paracerceis sculpta Holmes,1904 & & & & & & & & 1 & & & & $\mathrm{C}$ & IP & $\mathrm{S}$ \\
\hline Paradella dianae Menzies,1962 & & & & & & & & 1 & & & & E & Unk & ?S \\
\hline Sphaeroma walkeri (Stebbing, 1905) & & & & & & 1 & & 1 & & & & $\mathrm{E}$ & RS & $\mathrm{Su}$ \\
\hline \multicolumn{15}{|l|}{ Tanaidacea } \\
\hline Paradoxapseudes intermedius (Hansen, 1895) & & & 1 & & & & & & & & & $\mathrm{E}$ & AT & ?S \\
\hline \multicolumn{15}{|l|}{ Cumacea } \\
\hline Eocuma sarsii (Kossmann, 1880) & & & & 1 & & & & & & & & $\mathrm{E}$ & RS & $\mathrm{Su}$ \\
\hline \multicolumn{15}{|l|}{ Decapoda } \\
\hline Alpheus rapacida de Man, 1908 & & & & & & & & & & 1 & 1 & $\mathrm{E}$ & RS & $\mathrm{Su}$ \\
\hline Atergatis roseus (Rüppell, 1830) & & & & & 1 & 1 & & 1 & 1 & 1 & 1 & $\mathrm{E}$ & RS & $\mathrm{Su}$ \\
\hline Callinectes sapidus Rathbun, 1896 & 1 & & & & 1 & 1 & 1 & 1 & 1 & 1 & 1 & Inv & WA & $S$ \\
\hline
\end{tabular}


Table A1. Cont.

\begin{tabular}{|c|c|c|c|c|c|c|c|c|c|c|c|c|c|c|}
\hline Species List & Saros Bay & Ayvalık & Foça & Karaburun & Gökova Bay & Datça & Köyceğiz & Fethiye & Patara & Kaş-Kekova & Göksu & ES & $\mathrm{O}$ & PW \\
\hline Carupa tenuipes Dana, 1851 & & & & & & 1 & 1 & 1 & 1 & 1 & 1 & $\mathrm{E}$ & RS & $\mathrm{Su}$ \\
\hline Charybdis hellerii (Milne Edwards, 1867) & & & & & 1 & 1 & & 1 & & 1 & & Inv & RS & $\mathrm{Su}$ \\
\hline Charybdis longicollis Leene, 1938 & & & & & & 1 & & 1 & & & & Inv & RS & $\mathrm{Su}$ \\
\hline Coleusia signata (Paulson, 1875) & & & & & & & & 1 & 1 & 1 & 1 & $\mathrm{E}$ & RS & $\mathrm{Su}$ \\
\hline Eucrate crenata de Haan, 1835 & & & & & & & & & & & 1 & $\mathrm{E}$ & RS & $\mathrm{Su}$ \\
\hline Gonioinfradens giardi (Nobili, 1905) & & & & & & & & & & 1 & & $\mathrm{C}$ & IP & $\mathrm{s}$ \\
\hline Leptochela pugnax de Man, 1916 & & & & & 1 & & & 1 & & & & $\mathrm{E}$ & RS & $\mathrm{Su}$ \\
\hline Macrophthalmus indicus Davie, 2012 & & & & & 1 & & & & & & & $\mathrm{E}$ & RS & $\mathrm{Su}$ \\
\hline Matuta victor (Fabricius, 1781) & & & & & & & 1 & & & & & $\mathrm{E}$ & RS & $\mathrm{Su}$ \\
\hline Metapenaeopsis aegyptia Galil \& Golani, 1990 & & & & & & & & 1 & & 1 & & $\mathrm{E}$ & RS & $\mathrm{Su}$ \\
\hline $\begin{array}{l}\text { Metapenaeopsis mogiensis consobrina (Nobili, } \\
\text { 1904) }\end{array}$ & & & & & & & & & & 1 & & $\mathrm{E}$ & RS & $\mathrm{Su}$ \\
\hline Metapenaeus affinis (H. Milne Edwards, 1837) & & & & 1 & & & & & & & & $\mathrm{E}$ & RS & $\mathrm{Su}$ \\
\hline Metapenaeus stebbingi (Nobili, 1904) & & & & & & & & 1 & & & & Inv & RS & $\mathrm{Su}$ \\
\hline Micippa thalia (Herbst, 1803) & & & & & 1 & & & 1 & & 1 & & $\mathrm{E}$ & RS & $\mathrm{Su}$ \\
\hline Myra subgranulata Kossmann, 1877 & & & & & & & & 1 & 1 & 1 & 1 & $\mathrm{E}$ & RS & $\mathrm{Su}$ \\
\hline Palaemonella rotumana (Borradaile, 1898) & & & & & & & & 1 & & & & $\mathrm{E}$ & RS & $\mathrm{Su}$ \\
\hline Penaeus aztecus Ives, 1891 & 1 & & & 1 & & & & & & & & $\mathrm{E}$ & WA & $\mathrm{S}$ \\
\hline Penaeus hathor (Burkenroad, 1959) & & & & & 1 & & & 1 & & 1 & & Inv & RS & $\mathrm{Su}$ \\
\hline $\begin{array}{l}\text { Penaeus pulchricaudatus Stebbing, } 1914 \text { (=P. } \\
\text { japonicus) }\end{array}$ & & 1 & & & 1 & 1 & 1 & 1 & 1 & 1 & 1 & Inv & RS & $\mathrm{Su}$ \\
\hline Penaeus semisulcatus de Haan, 1844 & & & & & & & & 1 & 1 & 1 & 1 & Inv & RS & $\mathrm{Su}$ \\
\hline Percnon gibbesi (H. Milne Edwards, 1853) & & & & & 1 & 1 & 1 & 1 & & 1 & & Inv & $\mathrm{TA}$ & $\mathrm{S}$ \\
\hline Pilumnus minutus De Haan,1835 & 1 & & & 1 & & & & & & & & $\mathrm{E}$ & RS & $\mathrm{Su}$ \\
\hline Portunus segnis (Forskål, 1775) & & & & & 1 & 1 & 1 & 1 & & & 1 & Inv & RS & $\mathrm{Su}$ \\
\hline Processa macrodactyla Holthuis, 1952 & 1 & & & 1 & & & & & & & & $\mathrm{E}$ & $\mathrm{TA}$ & $\mathrm{S}$ \\
\hline Thalamita poissonii (Audouin, 1826) & & & & & 1 & 1 & & 1 & & 1 & 1 & $\mathrm{E}$ & RS & $\mathrm{Su}$ \\
\hline
\end{tabular}


Table A1. Cont.

\begin{tabular}{|c|c|c|c|c|c|c|c|c|c|c|c|c|c|c|}
\hline Species List & Saros Bay & Ayvalık & Foça & Karaburun & Gökova Bay & Datça & Köyceğiz & Fethiye & Patara & Kaş-Kekova & Göksu & ES & $\mathbf{O}$ & PW \\
\hline Trachysalambria palaestinensis Steinitz, 1932 & & & & & & & & 1 & 1 & 1 & 1 & E & RS & $\mathrm{Su}$ \\
\hline Urocaridella pulchella Yokes \& Galil, 2006 & & & & & & & & 1 & & 1 & & $\mathrm{E}$ & RS & $\mathrm{Su}$ \\
\hline \multicolumn{15}{|l|}{ Gastropoda } \\
\hline Diodora ruppellii (Sowerby I, G.B., 1835) & & & & & & & & & & & 1 & E & RS & $\mathrm{Su}$ \\
\hline Pseudominolia nedyma (Melville, 1897) & & & & & & & & & & & 1 & E & RS & $\mathrm{Su}$ \\
\hline $\begin{array}{l}\text { Smaragdia souverbiana (Montrouzier in } \\
\text { Souverbie \& Montrouzier, 1863) }\end{array}$ & & & & & & & & 1 & & & 1 & E & RS & $\mathrm{Su}$ \\
\hline Cerithidium perparvulum (Watson, R.B., 1886) & & & & & & & & & & & 1 & $\mathrm{E}$ & $\mathrm{PO}$ & $\mathrm{S}$ \\
\hline Cerithium scabridum Philippi, 1848 & 1 & & & & & 1 & & 1 & & 1 & 1 & Inv & RS & $\mathrm{Su}$ \\
\hline Rhinoclavis kochi (Philippi, 1848) & & & & & & & & & & & 1 & $\mathrm{E}$ & RS & $\mathrm{Su}$ \\
\hline Varicopeza pauxilla (A. Adams, 1855) & & & & & & & & & & & 1 & $\mathrm{E}$ & RS & $\mathrm{Su}$ \\
\hline Finella pupoides Adams, A., 1860 & & & & & & 1 & 1 & 1 & & & 1 & Inv & RS & $\mathrm{Su}$ \\
\hline Metaxia bacillum (Issel, 1869) & & & & & & & & & & & 1 & E & RS & $\mathrm{Su}$ \\
\hline Viriola bayani Jousseaume, 1884 & & & & & & & 1 & & & & & $\mathrm{E}$ & RS & $\mathrm{Su}$ \\
\hline Cerithiopsis tenthrenois (Melvill, 1896) & & & & & & & & & & & 1 & $\mathrm{E}$ & RS & $\mathrm{Su}$ \\
\hline Sticteulima lentiginosa (Adams, A., 1861) & & & & & & & & & & 1 & 1 & $\mathrm{E}$ & RS & $\mathrm{Su}$ \\
\hline Rissoina ambigua (Gould, 1849) & & & & & & & & & & 1 & & $\mathrm{C}$ & RS & $\mathrm{Su}$ \\
\hline Rissoina bertholleti Issel, 1869 & & & & 1 & & & & & & & 1 & $\mathrm{E}$ & RS & $\mathrm{Su}$ \\
\hline Conomurex persicus (Swainson, 1821) & & & & & 1 & 1 & 1 & 1 & 1 & 1 & 1 & Inv & PG & $S$ \\
\hline Purpuradusta gracilis notata (Gill, 1858) & & & & & & & & & & & 1 & $\mathrm{E}$ & RS & $\mathrm{Su}$ \\
\hline Ergalatax junionae Houart, 2008 & & & & & 1 & 1 & 1 & 1 & & 1 & 1 & $\mathrm{E}$ & RS & $\mathrm{S}$ \\
\hline Zafra savignyi (Moazzo, 1939) & & & & & & & & 1 & & & 1 & $\mathrm{E}$ & RS & $\mathrm{Su}$ \\
\hline Zafra selasphora (Melvill \& Standen, 1901) & & & & & & & & 1 & & & 1 & $\mathrm{E}$ & RS & $\mathrm{Su}$ \\
\hline Pyrgulina fischeri Hornung \& Mermod, 1925 & & & & & & & & & & & 1 & $\mathrm{E}$ & RS & $\mathrm{Su}$ \\
\hline Pyrgulina pupaeformis (Souverbie, 1865) & & & & & & & 1 & 1 & 1 & 1 & 1 & $\mathrm{E}$ & RS & $\mathrm{Su}$ \\
\hline Pyrgulina nana Hornung \& Mermod, 1924 & & & & & & & & & & & 1 & $\mathrm{C}$ & RS & ?S \\
\hline Pyrgulina pirinthella Melvill, 1910 & & & & & & & & & & & 1 & $\mathrm{E}$ & RS & $\mathrm{Su}$ \\
\hline Cingulina isseli (Tryon, 1886) & & & & & & & & & & & 1 & $\mathrm{E}$ & RS & $\mathrm{Su}$ \\
\hline
\end{tabular}


Table A1. Cont.

\begin{tabular}{|c|c|c|c|c|c|c|c|c|c|c|c|c|c|c|}
\hline Species List & Saros Bay & Ayvalık & Foça & Karaburun & Gökova Bay & Datça & Köyceğiz & Fethiye & Patara & Kaş-Kekova & Göksu & ES & $\mathrm{O}$ & PW \\
\hline Monotygma fulva (Adams, A., 1853) & & & & & & & & & & & 1 & E & RS & $\mathrm{Su}$ \\
\hline Monotygma lauta (Adams, A., 1853) & & & & & & & & & & & 1 & E & RS & $\mathrm{Su}$ \\
\hline Odostomia lorioli (Hornung \& Mermod, 1924) & & & & & & & & & & & 1 & E & RS & $\mathrm{Su}$ \\
\hline Oscilla galilae Bogi, Karhan \& Yokeş, 2012 & & & & & & & & & & & 1 & $\mathrm{C}$ & $\mathrm{IP}$ & ?S \\
\hline Syrnola fasciata Jickeli, 1882 & & & & & & & 1 & & 1 & & 1 & Inv & RS & $\mathrm{Su}$ \\
\hline Syrnola lendix (Adams, A., 1853) & & & & & & & & & & & 1 & E & $\mathrm{IO}$ & $\mathrm{Su}$ \\
\hline Turbonilla edgarii (Melvill, 1896) & & & & & & & & & & & 1 & E & RS & $\mathrm{Su}$ \\
\hline Leucotina natalensis Smith, E.A., 1910 & & & & & & & & & & & 1 & E & RS & $\mathrm{Su}$ \\
\hline Bulla arabica Malaquias \& Reid, 2008 & & & & & & & & & & 1 & 1 & E & RS & ?Su \\
\hline Pyrunculus fourierii (Audouin, 1826) & & & & & & & & 1 & & 1 & 1 & Inv & RS & $\mathrm{Su}$ \\
\hline Retusa desgenettii (Audouin, 1826) & & & & & & 1 & & & & & & E & RS & $\mathrm{Su}$ \\
\hline $\begin{array}{l}\text { Lamprohaminoea cyanomarginata (Heller \& } \\
\text { Thompson, T.E., 1983) }\end{array}$ & & & 1 & 1 & 1 & 1 & & 1 & 1 & 1 & & E & RS & $\mathrm{Su}$ \\
\hline Biuve fulvipunctata (Baba, 1938) & & & & & 1 & 1 & & & & & & E & RS & $\mathrm{Su}$ \\
\hline Acteocina mucronata (Philippi, 1849) & & & & & & & & & & & 1 & E & RS & $\mathrm{Su}$ \\
\hline Mnestia girardi (Audouin, 1826) & & & & & & & & & & & 1 & E & RS & $\mathrm{Su}$ \\
\hline Oxynoe viridis (Pease, 1861 ) & & & & & & & & 1 & 1 & 1 & & E & $\mathrm{IP}$ & $\mathrm{S}$ \\
\hline Elysia tomentosa Jensen, 1997 & & & & & & & & 1 & & & & E & ?IP & S \\
\hline Bursatella leachii Blainville, 1817 & & & & & & & & 1 & & 1 & & E & RS & ?Su \\
\hline $\begin{array}{l}\text { Syphonota geographica (Adams, A. \& Reeve, } \\
\text { 1850) }\end{array}$ & & & & & & & & 1 & & 1 & & E & RS & $\mathrm{Su}$ \\
\hline Goniobranchus annulatus (Eliot, 1904) & & & & & & & & & & 1 & & E & RS & $\mathrm{Su}$ \\
\hline $\begin{array}{l}\text { Hypselodoris infucata Rueppel \& Leuckart, } \\
1828\end{array}$ & & & & & & & & 1 & & 1 & 1 & E & RS & $\mathrm{Su}$ \\
\hline $\begin{array}{l}\text { Plocamopherus ocellatus Rüppell \& Leuckart, } \\
1828\end{array}$ & & & & & & & & & & 1 & & E & RS & $\mathrm{Su}$ \\
\hline Baeolidia moebii Bergh, 1888 & & & & & & & & & 1 & 1 & & $\mathrm{C}$ & RS & $\mathrm{Su}$ \\
\hline Coryphellina rubrolineata O'Donoghue, 1929 & & & & & 1 & 1 & & 1 & 1 & 1 & & E & RS & $\mathrm{Su}$ \\
\hline Siphonaria crenata Blainville 1827 & & & & & & & & & & & 1 & E & RS & $\mathrm{Su}$ \\
\hline
\end{tabular}


Table A1. Cont.

\begin{tabular}{|c|c|c|c|c|c|c|c|c|c|c|c|c|c|c|}
\hline Species List & Saros Bay & Ayvalık & Foça & Karaburun & Gökova Bay & Datça & Köyceğiz & Fethiye & Patara & Kaş-Kekova & Göksu & ES & $\mathrm{O}$ & PW \\
\hline \multicolumn{15}{|l|}{ Bivalvia } \\
\hline Brachidontes pharaonis (Fischer, P., 1870) & & & & 1 & 1 & 1 & 1 & 1 & 1 & 1 & 1 & Inv & RS & $\mathrm{Su}$ \\
\hline Clementia papyracea (Gmelin, 1791) & & & & & & & & & & & 1 & E & RS & $\mathrm{Su}$ \\
\hline Dendostrea folium (Linnaeus, 1758) & & & & & 1 & 1 & & 1 & & & & E & IP & ?S \\
\hline Ervilia scaliola Issel, 1869 & & & & & & & & & & & 1 & $\mathrm{C}$ & RS & $\mathrm{Su}$ \\
\hline Fulvia fragilis (Forsskål in Niebuhr, 1775) & & & & & & & & 1 & & & 1 & Inv & RS & $\mathrm{Su}$ \\
\hline Isognomon legumen (Gmelin, 1791) & & & & & & & 1 & & & & & E & RS & $\mathrm{Su}$ \\
\hline Magallana gigas (Thunberg, 1793) & & & & 1 & & & & & & & & E & $\mathrm{PO}$ & $\mathrm{Aq}$ \\
\hline Malleus regula (Forsskål in Niebuhr, 1775) & & & & & & 1 & & 1 & & 1 & & E & RS & $\mathrm{Su}$ \\
\hline Pinctada imbricata radiata (Leach, 1814) & & & & 1 & 1 & 1 & 1 & 1 & & 1 & 1 & Inv & RS & $\mathrm{Su}$ \\
\hline $\begin{array}{l}\text { Ruditapes philippinarum (Adams \& Reeve, } \\
\text { 1850) }\end{array}$ & 1 & & & & & & & & & & & Inv & $\mathrm{PO}$ & $\mathrm{Aq}$ \\
\hline Saccostrea cuccullata (Born, 1778) & & & & & & & & 1 & & & & E & IP & $\mathrm{S}$ \\
\hline Septifer cumingii Récluz, 1849 & & & & & & 1 & & 1 & & & & E & RS & $\mathrm{S}$ \\
\hline Teredothyra dominicensis (Bartsch, 1921) & & & & & & & & & & 1 & & E & WA & $\mathrm{S}$ \\
\hline \multicolumn{15}{|l|}{ Cephalopoda } \\
\hline Sepioteuthis lessoniana d'Orbignyi, 1826 & & & & & & & & 1 & & 1 & & Inv & RS & $\mathrm{Su}$ \\
\hline \multicolumn{15}{|l|}{ Bryozoa } \\
\hline Amathia verticillata (delle Chiaje, 1822) & & & & 1 & & & & 1 & & & & Inv & AT & $S$ \\
\hline Celleporaria brunnea (Hincks, 1884) & & & & 1 & & & & 1 & & & & Inv & $\mathrm{AT}$ & $\mathrm{S}$ \\
\hline \multicolumn{15}{|l|}{ Echinodermata } \\
\hline Ophiactis savignyi (Müller \& Troschel, 1842) & & & & & & & & 1 & & & & E & RS & $\mathrm{Su}$ \\
\hline Diadema setosum (Leske, 1778) & & & & & 1 & 1 & 1 & 1 & & 1 & & Inv & RS & $\mathrm{Su}$ \\
\hline Synaptula reciprocans (Forrskål, 1775) & & & & & 1 & 1 & 1 & 1 & 1 & 1 & 1 & Inv & RS & $\mathrm{Su}$ \\
\hline \multicolumn{15}{|l|}{ Tunicata } \\
\hline Ascidiella aspersa (Müller, 1776) & & & & & & & & 1 & & & & E & NA & S \\
\hline Clavelina oblonga Herdman, 1880 & & & & & & 1 & & & & & & E & WA & $\mathrm{S}$ \\
\hline Diplosoma listerianum (Milne Edwards, 1841) & & & 1 & & & & & 1 & & & & E & ?AT & $\mathrm{S}$ \\
\hline Microcosmus exasperatus Heller, 1878 & & & & & & 1 & & 1 & & & & E & RS & $\mathrm{Su}$ \\
\hline
\end{tabular}


Table A1. Cont.

\begin{tabular}{|c|c|c|c|c|c|c|c|c|c|c|c|c|c|c|}
\hline Species List & Saros Bay & Ayvalık & Foça & Karaburun & Gökova Bay & Datça & Köyceğiz & Fethiye & Patara & Kaş-Kekova & Göksu & ES & $\mathrm{O}$ & PW \\
\hline Phallusia nigra Savignyi, 1816 & & & & & & & & 1 & 1 & 1 & 1 & Inv & WA & ?S \\
\hline Pyura (=Herdmania) momus (Savigny, 1816) & & & & & & & 1 & 1 & 1 & 1 & & $\mathrm{E}$ & RS & $\mathrm{Su}$ \\
\hline Rhodosoma turcicum (Savigny, 1816) & & & & & & & & 1 & & & & $\mathrm{E}$ & $\mathrm{CT}$ & $\mathrm{S}$ \\
\hline Styela plicata (Lesueur, 1823) & & & 1 & & & 1 & & 1 & & & & Inv & ?AT & $\mathrm{S}$ \\
\hline Symplegma brakenhielmi (Michaelsen, 1904) & & & & & & & & 1 & & & & Inv & RS & $\mathrm{Su}$ \\
\hline \multicolumn{15}{|l|}{ Actinopterygii } \\
\hline Alepes djedaba (Forsskål, 1775) & & & & & 1 & 1 & 1 & 1 & 1 & 1 & 1 & Inv & RS & $\mathrm{Su}$ \\
\hline Apogonichthyoides pharaonis (Bellotti, 1874) & & & & & 1 & 1 & 1 & 1 & 1 & 1 & 1 & $\mathrm{E}$ & RS & $\mathrm{Su}$ \\
\hline Atherinomorus forskalii (Rüppell, 1838) & & & & & 1 & 1 & 1 & 1 & 1 & 1 & 1 & Inv & RS & $\mathrm{Su}$ \\
\hline Bregmaceros nectabanus Whitley, 1941 & & & 1 & 1 & 1 & 1 & 1 & 1 & 1 & 1 & 1 & $\mathrm{E}$ & RS & $\mathrm{Su}$ \\
\hline Callionymus filamentosus Valenciennes, 1837 & & & & & & & 1 & 1 & 1 & 1 & 1 & $\mathrm{E}$ & RS & $\mathrm{Su}$ \\
\hline Champsodon nudivittis (Ogilby, 1895) & & 1 & 1 & & 1 & 1 & 1 & 1 & 1 & 1 & 1 & Inv & RS & $\mathrm{Su}$ \\
\hline Cheilodipterus novemstriatus (Rüppell, 1838) & & & & & & & & & & 1 & 1 & $\mathrm{E}$ & RS & $\mathrm{Su}$ \\
\hline Diplogrammus randalli Fricke, 1983 & & & & & & & & 1 & & & & $\mathrm{C}$ & RS & $\mathrm{Su}$ \\
\hline Dussumieria elopsoides Bleeker, 1849 & & & & & & & & & & & 1 & Inv & RS & $\mathrm{Su}$ \\
\hline Equulites klunzingeri (Steindachner, 1898) & & & & & 1 & 1 & 1 & 1 & 1 & 1 & 1 & Inv & RS & $\mathrm{Su}$ \\
\hline Equulites popei (Whitley, 1932) & & & & & & & & & & & 1 & Inv & RS & $\mathrm{Su}$ \\
\hline $\begin{array}{l}\text { Etrumeus golanii DiBatistta, Randall and } \\
\text { Bowen, } 2012\end{array}$ & & & 1 & & 1 & 1 & 1 & 1 & 1 & 1 & 1 & Inv & RS & $\mathrm{Su}$ \\
\hline Fistularia commersonii (Rüppell, 1835) & & & & & 1 & 1 & 1 & 1 & 1 & 1 & 1 & Inv & RS & $\mathrm{Su}$ \\
\hline Fistularia petimba Lacepède, 1803 & & & & & 1 & 1 & 1 & 1 & 1 & 1 & 1 & Inv & RS & $\mathrm{Su}$ \\
\hline Hazeus ingressus Engin, Larson, Irmak, 2018 & & & & & & & & 1 & & & & $\mathrm{C}$ & RS & $\mathrm{Su}$ \\
\hline Hemiramphus far (Forsskål, 1775) & & & 1 & 1 & 1 & 1 & 1 & 1 & 1 & 1 & 1 & $\mathrm{E}$ & RS & $\mathrm{Su}$ \\
\hline Herklotsichthys punctatus (Rüppell, 1837) & & & & & & & & & & & 1 & $\mathrm{E}$ & RS & $\mathrm{Su}$ \\
\hline Jaydia queketti (Gilchrist, 1903) & & & & & 1 & 1 & 1 & 1 & 1 & 1 & 1 & $\mathrm{E}$ & RS & $\mathrm{Su}$ \\
\hline Jaydia smithi Kotthaus, 1970 & & & & & & & & & & & 1 & $\mathrm{E}$ & RS & $\mathrm{Su}$ \\
\hline
\end{tabular}


Table A1. Cont.

\begin{tabular}{|c|c|c|c|c|c|c|c|c|c|c|c|c|c|c|}
\hline Species List & Saros Bay & Ayvalık & Foça & Karaburun & Gökova Bay & Datça & Köyceğiz & Fethiye & Patara & Kaş-Kekova & Göksu & ES & $\mathrm{O}$ & PW \\
\hline Lagocephalus guentheri (Richardson, 1844) & & & & & 1 & 1 & 1 & 1 & 1 & 1 & 1 & Inv & RS & $\mathrm{Su}$ \\
\hline Lagocephalus sceleratus (Gmelin, 1789) & 1 & 1 & 1 & 1 & 1 & 1 & 1 & 1 & 1 & 1 & 1 & Inv & RS & $\mathrm{Su}$ \\
\hline Lagocephalus suezensis Clark \& Gohar, 1953 & & & & & 1 & 1 & 1 & 1 & 1 & 1 & 1 & Inv & RS & $\mathrm{Su}$ \\
\hline Liza carinata (Valenciennes, 1836) & & & & & & & & & & & 1 & $\mathrm{E}$ & RS & $\mathrm{Su}$ \\
\hline Nemipterus randalli Russell, 1986 & & & & & 1 & 1 & 1 & 1 & 1 & 1 & 1 & Inv & RS & $\mathrm{Su}$ \\
\hline Ostorhinchus fasciatus (White, 1790) & & & & & 1 & 1 & 1 & 1 & 1 & 1 & 1 & E & RS & $\mathrm{Su}$ \\
\hline Paranthias furcifer (Valenciennes, 1828) & & & & & & & & & & 1 & & $\mathrm{C}$ & AT & $?$ \\
\hline Parexocoetus mento (Valenciennes, 1846) & & & & & 1 & 1 & 1 & 1 & 1 & 1 & 1 & $\mathrm{E}$ & RS & $\mathrm{Su}$ \\
\hline $\begin{array}{l}\text { Parupeneus forskalli (Fourmanoir \& Guézé, } \\
\text { 1976) }\end{array}$ & & & & & 1 & 1 & 1 & 1 & 1 & 1 & 1 & Inv & RS & $\mathrm{Su}$ \\
\hline Pelates quadrilineatus (Bloch, 1790) & & & & & & & & & & & 1 & $\mathrm{E}$ & RS & $\mathrm{Su}$ \\
\hline $\begin{array}{l}\text { Pempheris rhomboidea Kossmann \& Räuber, } \\
1877\end{array}$ & & & & & 1 & 1 & 1 & 1 & 1 & 1 & 1 & $\mathrm{E}$ & RS & $\mathrm{Su}$ \\
\hline Petroscirtes ancylodon Rüppell, 1838 & & & & & 1 & & & & & & & $\mathrm{E}$ & RS & $\mathrm{Su}$ \\
\hline Pomadasys stridens (Forsskål, 1775) & & & & & & & & & & & 1 & E & RS & $\mathrm{Su}$ \\
\hline Priacanthus sagittarius Starnes, 1988 & & & & & & & & & & & 1 & $\mathrm{C}$ & RS & $\mathrm{Su}$ \\
\hline Pteragogus trispilus Randall, 2013 & & & & & 1 & 1 & 1 & 1 & 1 & 1 & 1 & $\mathrm{E}$ & RS & $\mathrm{Su}$ \\
\hline Pterois miles (Bennett, 1828) & & & & 1 & 1 & 1 & 1 & 1 & 1 & 1 & 1 & Inv & RS & $\mathrm{Su}$ \\
\hline Sargocentron rubrum (Forsskål, 1775) & & & & & 1 & 1 & 1 & 1 & 1 & 1 & 1 & $\mathrm{E}$ & RS & $\mathrm{Su}$ \\
\hline $\begin{array}{l}\text { Saurida lessepsianus (Russell, Golani and } \\
\text { Tikochinski, 2015) }\end{array}$ & & & & & 1 & 1 & 1 & 1 & 1 & 1 & 1 & Inv & RS & $\mathrm{Su}$ \\
\hline Scarus ghobban Forsskål, 1775 & & & & & & & & & & 1 & & $\mathrm{C}$ & RS & $\mathrm{Su}$ \\
\hline Scomberomorus commerson Lacepède, 1800 & & & & & 1 & 1 & 1 & 1 & 1 & 1 & 1 & E & RS & $\mathrm{Su}$ \\
\hline Siganus luridus (Rüppell, 1829) & & 1 & 1 & 1 & 1 & 1 & 1 & 1 & 1 & 1 & 1 & Inv & RS & $\mathrm{Su}$ \\
\hline Siganus rivulatus Forsskål, 1775 & 1 & 1 & 1 & 1 & 1 & 1 & 1 & 1 & 1 & 1 & 1 & Inv & RS & $\mathrm{Su}$ \\
\hline $\begin{array}{l}\text { Sillago suezensis Golani, Fricke and } \\
\text { Tikochinski, } 2014\end{array}$ & & & & & & 1 & & & & & 1 & $\mathrm{E}$ & RS & $\mathrm{Su}$ \\
\hline
\end{tabular}


Table A1. Cont.

\begin{tabular}{|c|c|c|c|c|c|c|c|c|c|c|c|c|c|c|}
\hline Species List & Saros Bay & Ayvalık & Foça & Karaburun & Gökova Bay & Datça & Köyceğiz & Fethiye & Patara & Kaş-Kekova & Göksu & ES & $\mathrm{O}$ & PW \\
\hline Sphyraena chrysotaenia Klunzinger, 1884 & & & 1 & 1 & 1 & 1 & 1 & 1 & 1 & 1 & 1 & Inv & RS & $\mathrm{Su}$ \\
\hline Sphyraena flavicauda Rüppell, 1838 & & & & & & & 1 & 1 & 1 & 1 & 1 & Inv & RS & $\mathrm{Su}$ \\
\hline Stephanolepis diaspros Fraser-Brunner, 1940 & & & & & 1 & 1 & 1 & 1 & 1 & 1 & 1 & $\mathrm{E}$ & RS & $\mathrm{Su}$ \\
\hline Synchiropus sechellensis Regan, 1908 & & & & & & & & & & 1 & & $\mathrm{E}$ & RS & $\mathrm{Su}$ \\
\hline $\begin{array}{l}\text { Torquigener flavimaculosus Hardy \& Randall, } \\
1983\end{array}$ & & & & & 1 & 1 & 1 & 1 & 1 & 1 & 1 & Inv & RS & $\mathrm{Su}$ \\
\hline Tylerius spinosissimus (Regan, 1908) & & & & & & & & & & & 1 & $\mathrm{C}$ & RS & $\mathrm{Su}$ \\
\hline Upeneus pori Ben-Tuvia \& Golani, 1989 & & & & & 1 & 1 & 1 & 1 & 1 & 1 & 1 & Inv & RS & $\mathrm{Su}$ \\
\hline Vanderhorstia mertensi Klausewitz, 1974 & & & & & 1 & 1 & 1 & 1 & 1 & 1 & 1 & $\mathrm{E}$ & RS & $\mathrm{Su}$ \\
\hline
\end{tabular}




\section{References}

1. Meola, B.; Webster, C. The 2016 Status of Marine Protected Areas in the Mediterranean; MedPAN \& RAC/SPA: Tunis, Tunisia, 2019; p. 222.

2. Gabrié, C.; Lagabrielle, E.; Bissery, C.; Crochelet, E.; Meola, B.; Webster, C.; Claudet, J.; Chassanite, A.; Marinesque, S.; Robert, P. The Status of Marine Protected Areas in the Mediterranean Sea 2012; MedPAN \& RAC/SPA: Marseille, France, $2012 ;$ p. 257.

3. Gownaris, N.J.; Santora, C.M.; Davis, J.B.; Pikitch, E.K. Gaps in protection of important ocean areas: A spatial meta-analysis of ten global mapping initiatives. Front. Mar. Sci. 2019, 6, 1-15. [CrossRef]

4. Kelleher, G. Guidelines for Marine Protected Areas; IUCN: Gland, Switzerland; Cambridge, UK, 1999; p. 107.

5. Rodríguez-Rodríguez, D.; Merkohasanaj, M.; Lopez, I. Social and economic sustainability of multiple-use marine protected areas in Spain: A mixed methods, multi-scale study. Ocean Coast. Manag. 2019, 171, 47-55. [CrossRef]

6. Sala, E.; Giakoumi, S. No-take marine reserves are the most effective protected areas in the ocean. Ices J. Mar. Sci. 2018, 75, 1166-1168. [CrossRef]

7. MedPAN; UNEP/MAP-RAC/SPA. The 2016 Status of Marine Protected Areas in the Mediterranean Main Findings; MedPAN \& RAC/SPA: Marseille, France, 2016; p. 16.

8. Gomei, M.; Abdulla, A.; Schröder, C.; Yadav, S.; Sánchez, A.; Rodríguez, D.; Abdul Malak, D. Towards 2020: How Mediterranean Countries Are Performing to Protect Their Sea; WWF: Malaga, Spain, 2019; p. 38.

9. Bruno, J.F.; Bates, A.E.; Cacciapaglia, C.; Pike, E.P.; Amstrup, S.C.; van Hooidonk, R.; Henson, S.A.; Aronson, R.B. Climate change threatens the world's marine protected areas. Nat. Clim. Chang. 2018, 8, 499-503. [CrossRef]

10. Galil, B. Eyes wide shut: Managing bio-invasions in Mediterranean marine protected areas. In Management of Marine Protected Areas: A Network Perspective; Goriup, P.D., Ed.; John Wiley \& Sons Ltd: Oxford, UK, 2017; pp. 187-206.

11. Katsanevakis, S.; Coll, M.; Piroddi, C.; Steenbeek, J.; Lasram, F.B.; Zenetos, A.; Cardoso, A.C. Invading the Mediterranean Sea: Biodiversity patterns shaped by human activities. Front. Mar. Sci. 2014, 1, 1-11. [CrossRef]

12. Çinar, M.E.; Bilecenoglu, M.; Yokes, M.B.; Ozturk, B.; Taskin, E.; Bakir, K.; Dogan, A.; Acik, S. Current status (as of end of 2020) of marine alien species in Turkey. PLoS ONE 2021, 16, e0251086. [CrossRef]

13. Coll, M.; Piroddi, C.; Steenbeek, J.; Kaschner, K.; Lasram, F.B.; Aguzzi, J.; Ballesteros, E.; Bianchi, C.N.; Corbera, J.; Dailianis, T.; et al. The biodiversity of the Mediterranean Sea: Estimates, patterns, and threats. PLoS ONE 2010, 5, e11842. [CrossRef]

14. Mannino, A.M.; Parasporo, M.; Crocetta, F.; Balistreri, P. An updated overview of the marine alien and cryptogenic species from the Egadi Islands Marine Protected Area (Italy). Mar. Biodivers. 2017, 47, 469-480. [CrossRef]

15. Monaco, A.; Genovesi, P. European Guidelines on Protected Areas and Invasive Alien Species; Council of Europe and Regional Parks Agency: Rome, Italy, 2014; p. 60.

16. Burfeind, D.D.; Pitt, K.A.; Connolly, R.M.; Byers, J.E. Performance of non-native species within marine reserves. Biol. Invasions 2013, 15, 17-28. [CrossRef]

17. D'Amen, M.; Azzurro, E. Lessepsian fish invasion in Mediterranean marine protected areas: A risk assessment under climate change scenarios. Ices J. Mar. Sci. 2020, 77, 388-397. [CrossRef]

18. Mazaris, A.D.; Katsanevakis, S. The threat of biological invasions is under-represented in the marine protected areas of the European Natura 2000 network. Biol. Conserv. 2018, 225, 208-212. [CrossRef]

19. Belle, E.; Kingston, N.; Burgess, N.; Sandwith, T.; Ali, N.; MacKinnon, K. Protected Planet Report 2018, Tracking Progress towards Global Targets for Protected Areas; UNEP-WCMC, IUCN \& NGS: Cambridge, UK; Gland, Switzerland; Washington, DC, USA, 2018; p. 70 .

20. Okus, E.; Sur, H.; Yuksek, A.; Yilmaz, I.; Aslan-Yilmaz, A.; Karhan, S.; Oz, M.; Demirel, N.; Tas, S.; Altiok, A. Datça-Bozburun özel Çevre Koruma Bölgesinin Denizsel ve Kıyısal Alanlarının Biyolojik Çeşitlilï̆̈inin Tespiti Final Raporu; T.C. Çevre ve Orman Bakanlı̆̆ı Özel Çevre Koruma Kurumu Başkanlığı: Ankara, Turkey, 2004; p. 291. (In Turkish)

21. Okus, E.; Yüksek, A.; Yokes, M.B.; Yilmaz, I.N.; Aslan-Yilmaz, A.; Karhan, S.U.; Demirel, N.; Demir, V.; Zeki, S.; Tas, S.; et al Gökova Özel Çevre Koruma Bölgesinin kıyı ve deniz Alanlarının Biyolojik Çeşitliliginin Tespiti Projesi Final Raporu; T.C. Çevre ve Orman Bakanlı̆̆ Özel Çevre Koruma Kurulu Başkanlığı: Ankara, Turkey, 2006; p. 352.

22. Çinar, M.E.; Kocatas, A.; Katagan, T.; Yilmaz, A.; Onen, M.; Tarkan, A.N.; Yalciner, A.C.; Oztürk, B.; Bilecenoglu, M.; Düzgün, Ş.; et al. Fethiye Göcek özel Çevre Koruma Bölgesi Kiyi ve Deniz Alanlarinin Biyolojik Çeşitlilik Tespiti Projesi Final Raporu; T.C. Çevre ve Orman Bakanligi Özel Çevre Koruma Kurumu Başkanliği: Ankara, Turkey, 2010; p. 299.

23. UNEP-MAP. Action Plan Concerning Species Introductions and Invasive Species in the Mediterranean Sea; UN Environment/MAP: Athens, Greece, 2017; p. 14.

24. MoAF. National Biodiversity Action Plan 2018-2028; Republic of Turkey, Ministry of Agriculture and Forestry (MoAF), General Directorate of Nature Conservation and National Parks: Ankara, Turkey, 2019; p. 118.

25. Marchini, A.; Galil, B.S.; Occhipinti-Ambrogi, A. Recommendations on standardizing lists of marine alien species: Lessons from the Mediterranean Sea. Mar. Pollut. Bull. 2015, 101, 267-273. [CrossRef] [PubMed]

26. Latombe, G.; Pysek, P.; Jeschke, J.M.; Blackburn, T.M.; Bacher, S.; Capinha, C.; Costello, M.J.; Fernandez, M.; Gregory, R.D.; Hobern, D.; et al. A vision for global monitoring of biological invasions. Biol. Conserv. 2017, 213, 295-308. [CrossRef] 
27. Vanderhoeven, S.; Adriaens, T.; Desmet, P.; Strubbe, D.; Backeljau, T.; Barbier, Y.; Brosens, D.; Cigar, J.; Coupremanne, M.; De Troch, R.; et al. Tracking Invasive Alien Species (TrIAS): Building a data-driven framework to inform policy. Res. Ideas Outcomes 2017, 3, e13414. [CrossRef]

28. Zenetos, A.; Galanidi, M. Mediterranean non indigenous species at the start of the 2020s: Recent changes. Mar. Biodivers. Rec. 2020, 13, 1-17. [CrossRef]

29. Çinar, M.E.; Bilecenoglu, M. Preface-special issue on: Marine animal diversity of Turkey. Turk. J. Zool 2014, 38, i-ii.

30. Bizsel, K.C.; Kozludere, S.; Besiktepe, S.; Bizsel, N.; Sayin, E.; Yüksek, A.; Kaboglu, G.; Akçali, B.; Yilmaz, E.C.; Kavcioglu, R.; et al. Köyceğiz-Dalyan özel Çevre Koruma Bölgesi Deniz ve kıyı Alanlarında Biyolojik Çeşitliliğin Tespiti Projesi Sonuç Raporu; T.C. Çevre ve Orman Bakanlığı Özel Çevre Koruma Kurumu Başkanlı̆̆1: Ankara, Turkey, 2010; p. 206.

31. SualtiArastirmalariDernegi. Foça özel Çevre Koruma Bölgesi kıyı Alanları Taşıma Kapasitesinin Belirlenmesi Projesi; T.C. Çevre ve Orman Bakanlığı Özel Çevre Koruma Kurumu Başkanlığı: Ankara, Turkey, 2008; p. 528.

32. Tural, U. MedPAN South Turkey Pilot Project, Developing a Management Plan for Kaş-Kekova Specially Protected Area (Spa); WWF MedPO: İstanbul, Turkey, 2012; p. 20.

33. Yigit, N.; Albay, M.; Altinagaç, U.; Okudan Aslan, E.S.; Cevik, C.; Muftuoglu, E.; Balkis, N.; Topçu, N.E.; Kuyucuoglu, B.; Dalyan, C.; et al. Saros Körfezi Özel Çevre Koruma Bölgesi Karasal ve Denizel Biyolojik Çeşitliliğin Tespiti Projesi; T.C. Çevre ve Şehircilik Bakanlığı Tabiat Varlıklarını Koruma Genel Müdürlüğü: Ankara, Turkey, 2014; p. 427.

34. Clarke, K.R.; Warwick, R.M. Change in Marine Communities: An Approach to Statistical Analysis and Interpretation; Natural Environment Research Council: Swindon, UK, 1994.

35. Çinar, M.E.; Bilecenoglu, M.; Ozturk, B.; Katagan, T.; Yokes, M.B.; Aysel, V.; Dagli, E.; Acik, S.; Ozcan, T.; Erdogan, H. An updated review of alien species on the coasts of Turkey. Mediterr. Mar. Sci. 2011, 12, 257-315. [CrossRef]

36. Olden, J.D.; Comte, L.; Giam, X. Biotic homogenisation. In eLS; John Wiley \& Sons, Ltd: Chichester, UK, 2016 ; pp. 1-8.

37. Galil, B.S.; Mienis, H.K.; Hoffman, R.; Goren, M. Non-indigenous species along the Israeli Mediterranean coast: Tally, policy, outlook. Hydrobiologia 2021, 848, 2011-2029. [CrossRef]

38. Servello, G.; Andaloro, F.; Azzurro, E.; Castriota, L.; Catra, M.; Chiarore, A.; Crocetta, F.; D’alessandro, M.; Denitto, F.; Froglia, C.; et al. Marine alien species in Italy: A contribution to the implementation of descriptor D2 of the marine strategy framework directive. Mediterr. Mar. Sci. 2019, 20, 1-48. [CrossRef]

39. Zenetos, A.; Corsini-Foka, M.; Crocetta, F.; Gerovasileiou, V.; Karachle, P.K.; Simboura, N.; Tsiamis, K.; Pancucci-Papadopoulou, M.-A. Deep cleaning of alien and cryptogenic species records in the Greek Seas (2018 update). Manag. Biol. Invasions 2018, 9, 209-226. [CrossRef]

40. Ounifi-Ben Amor, K.; Rifi, M.; Ghanem, R.; Draeif, I.; Zaouali, J.; Ben Souissi, J. Update of alien fauna and new records from Tunisian marine waters. Mediterr. Mar. Sci. 2016, 17, 124-143. [CrossRef]

41. Shakman, E.; Eteayb, K.; Taboni, I.; Ben Abdalla, A. Status of marine alien species along the Libyan coast. J. Black Sea/Mediterr. Environ. 2019, 25, 188-209.

42. Otero, M.; Cebrian, E.; Francour, P.; Galil, B.; Savini, D. Monitoring Marine Invasive Species in Mediterranean Marine Protected Areas (Mpas), A Strategy and Practical Guide for Managers; IUCN: Malaga, Spain, 2013; p. 136.

43. Giakoumi, S.; Pey, A. Assessing the Effects of Marine Protected Areas on Biological Invasions: A Global Review. Front. Mar. Sci. 2017, 4, 1-6. [CrossRef]

44. Reise, K.; Olenin, S.; Thieltges, D.W. Are aliens threatening European aquatic coastal ecosystems? Helgol. Mar. Res. 2006, 60, 77-83. [CrossRef]

45. Huseyinoglu, M.F.; Demir, V.; Arda, Y.; Draman, M.; Yokes, M.B. Spatio-temporal distribution of lionfish, Pterois miles (Bennett, 1828) in Kas-Kekova Special Environmental Protected Area, Turkey. Estuar. Coast. Shelf Sci. 2021, 254, 107331. [CrossRef]

46. Giakoumi, S.; Guilhaumon, F.; Kark, S.; Terlizzi, A.; Claudet, J.; Felline, S.; Cerrano, C.; Coll, M.; Danovaro, R.; Fraschetti, S.; et al. Space invaders; biological invasions in marine conservation planning. Divers. Distrib. 2016, 22, 1220-1231. [CrossRef]

47. Giakoumi, S.; Katsanevakis, S.; Albano, P.G.; Azzurro, E.; Cardoso, A.C.; Cebrian, E.; Deiduni, A.; Edelist, D.; Francour, P.; Jimenez, C.; et al. Management priorities for marine invasive species. Sci. Total Environ. 2019, 688, 976-982. [CrossRef]

48. Guidetti, P.; Baiata, P.; Ballesteros, E.; Di Franco, A.; Hereu, B.; Macpherson, E.; Micheli, F.; Pais, A.; Panzalis, P.; Rosenberg, A.A. Large-scale assessment of Mediterranean marine protected areas effects on fish assemblages. PLoS ONE 2014, 9, e91841. [CrossRef]

49. Mannino, A.M.; Balistreri, P. Invasive alien species in Mediterranean Marine Protected Areas: The Egadi Islands (Italy) case study. Biodiversity 2021, 22, 13-23. [CrossRef] 